\title{
Highly focused anopheline breeding sites and malaria transmission in Dakar
}

\author{
Vanessa Machault 1,2,3,4, Libasse Gadiaga7,8, Cécile Vignolles ${ }^{5}$, \\ Fanny Jarjaval1,2, Samia Bouzid ${ }^{1,2}$, Cheikh Sokhna7,8, Jean-Pierre Lacaux ${ }^{6}$, \\ Jean-François Trape ${ }^{7,8}$, Christophe Rogier ${ }^{3,4}$ and Frédéric Pagès*1,2
}

\begin{abstract}
Address: ${ }^{1}$ Unité d'entomologie médicale, Equipe 7 "Maladies émergentes et moustiques", Institut de Médecine Tropicale du Service de Santé des Armées, Allée du Médecin colonel Jamot, Parc du Pharo, BP60109, 13262 Marseille cedex 07, France, ²Unité de Recherche sur les Maladies Infectieuses et Tropicales Emergentes - URMITE - UMR6236, Institut de Médecine Tropicale du Service de Santé des Armées, Allée du Médecin colonel Jamot, Parc du Pharo, BP60109, 13262 Marseille cedex 07, France, ${ }^{3}$ Unité de recherche en biologie et épidémiologie parasitaires, Equipe 7 "Maladies émergentes et moustiques", Institut de Médecine Tropicale du Service de Santé des Armées, Allée du Médecin colonel Jamot, Parc du Pharo, BP60109, 13262 Marseille cedex 07, France, ${ }^{4}$ Unité de Recherche sur les Maladies Infectieuses et Tropicales Emergentes - URMITE UMR6236, Institut de Médecine Tropicale du Service de Santé des Armées, Allée du Médecin colonel Jamot, Parc du Pharo, BP60109, 13262 Marseille cedex 07, France, ${ }^{5}$ Centre National d'Etudes Spatiales - Application Valorisation - 18 avenue Edouard Belin, 31401 Toulouse Cedex 9, France, ${ }^{6}$ Observatoire Midi-Pyrénées, Université Paul Sabatier, 14 avenue Edouard Belin, 31400 Toulouse, France, ${ }^{7}$ Unité de Paludologie Afrotropicale, Equipe 7 "Maladies émergentes et moustiques", Institut de Recherche pour le Développement, Route des Pères Maristes, BP 1386, 18524 Dakar, Sénégal and ${ }^{8}$ Unité de Recherche sur les Maladies Infectieuses et Tropicales Emergentes - URMITE - UMR6236, Institut de Recherche pour le Développement, Route des Pères Maristes, BP 1386, 18524 Dakar, Sénégal
\end{abstract}

Email: Vanessa Machault - vanessamachault@yahoo.com.br; Libasse Gadiaga - gadiagalibass@yahoo.fr;

Cécile Vignolles - cecile.vignolles@cnes.fr; Fanny Jarjaval - entomo@imtssa.fr; Samia Bouzid - samia.bouzid@laposte.net;

Cheikh Sokhna - cheikh.sokhna@ird.sn; Jean-Pierre Lacaux - jean-pierre.lacaux@medias.cnes.fr; Jean-François Trape - trape@ird.sn;

Christophe Rogier - christophe.rogier@wanadoo.fr; Frédéric Pagès* - frederic_pages@yahoo.com

* Corresponding author

Published: 24 June 2009

Malaria Journal 2009, 8:138 doi:10.1186/1475-2875-8-138
Received: 18 March 2009

Accepted: 24 June 2009

This article is available from: http://www.malariajournal.com/content/8/I//38

(c) 2009 Machault et al; licensee BioMed Central Ltd.

This is an Open Access article distributed under the terms of the Creative Commons Attribution License (http://creativecommons.org/licenses/by/2.0), which permits unrestricted use, distribution, and reproduction in any medium, provided the original work is properly cited.

\begin{abstract}
Background: Urbanization has a great impact on the composition of the vector system and malaria transmission dynamics. In Dakar, some malaria cases are autochthonous but parasite rates and incidences of clinical malaria attacks have been recorded at low levels. Ecological heterogeneity of malaria transmission was investigated in Dakar, in order to characterize the Anopheles breeding sites in the city and to study the dynamics of larval density and adult aggressiveness in ten characteristically different urban areas.

Methods: Ten study areas were sampled in Dakar and Pikine. Mosquitoes were collected by human landing collection during four nights in each area (I20 person-nights). The Plasmodium falciparum circumsporozoite (CSP) index was measured by ELISA and the entomological inoculation rates (EIR) were calculated. Open water collections in the study areas were monitored weekly for physico-chemical characterization and the presence of anopheline larvae. Adult mosquitoes and hatched larvae were identified morphologically and by molecular methods.

Results: In September-October 2007, 19,45 I adult mosquitoes were caught among which, I,I0 I were Anopheles gambiae s.l. The Human Biting Rate ranged from 0.1 bites per person per night in Yoff Village to 43.7 in Almadies. Seven out of I, I0I An. gambiae s.l. were found to be positive for $P$. falciparum (CSP index $=0.64 \%$ ). EIR ranged from 0 infected bites per person per year in Yoff
\end{abstract}


Village to 16.8 in Almadies. The An. gambiae complex population was composed of Anopheles arabiensis (94.8\%) and Anopheles melas (5.2\%). None of the An. melas were infected with $P$. falciparum. Of the 54 water collection sites monitored, 33 (6I.1\%) served as anopheline breeding sites on at least one observation. No An. melas was identified among the larval samples. Some physico-chemical characteristics of water bodies were associated with the presence/absence of anopheline larvae and with larval density. A very close parallel between larval and adult densities was found in six of the ten study areas.

Conclusion: The results provide evidence of malaria transmission in downtown Dakar and its surrounding suburbs. Spatial heterogeneity of human biting rates was very marked and malaria transmission was highly focal. In Dakar, mean figures for transmission would not provide a comprehensive picture of the entomological situation; risk evaluation should therefore be undertaken on a small scale.

\section{Background}

\section{Malaria and urbanization}

Urbanization has a significant impact on the health of local populations. It is estimated that by 2025, 800 million people will live in African cities and urban malaria is considered to be an emerging health problem of major importance in Africa. Urban malaria should be seen as a specific public health issue and assessment, understanding and control should not simply reproduce initiatives taken in rural communities $[1,2]$.

In urban settings, malaria risk heterogeneity is recorded over small distances due to diversity in the degree and type of urbanization, density of human population, quality of water and waste management, vector control measures, household factors and access to health care [1,3], or human migration patterns that might import parasites from rural areas [4]. Urbanization has a great impact on the composition of the vector system and malaria transmission dynamics [5]. In regard to breeding requirements, there is evidence of adaptation of anopheline species to urban settings and several examples of polluted breeding habitats or new types of breeding habitats have been brought to light [6-9]. The importance of urban agricultural activity on malaria has also been reported in several African cities, such as in Côte d'Ivoire and Ghana [10], where irrigation leads to the creation of larval habitats $[10,11]$ and higher malaria prevalence $[12,13]$.

Finally, variations in Anopheles densities play a major role in the spatial and temporal heterogeneity of malaria risk. In cities, where blood meal sources are abundant, dispersion of the vectors is low and malaria transmission is focal and highly driven by the proximity of breeding sites $[14,15]$. Thus, an understanding of transmission heterogeneity requires a good knowledge of the geographical localization of breeding sites. Characterizing and mapping these habitats will help to spatially rank malaria risk in urban settings and focus control activities on a small scale [16].

\section{Clinical malaria in Dakar}

In Dakar, the capital city of Senegal, some malaria cases are recognized to be autochthonous [17] but parasite rates and incidences of clinical malaria attacks in the city and its nearby periphery have been recorded at low levels compared to continent-wide level $[14,17,18]$. Nevertheless, malaria should not be neglected, as severe cases have been reported among Dakar residents with little acquired malaria immunity [19]. In some health facilities, up to $65 \%$ of patients diagnosed with malaria present severe forms of the disease [20]. In Dakar, a high prevalence of severe anaemia was found in young children between 1990 and 1996 [21] and placental malaria infections have been associated with pre-eclampsia in pregnant women with poor malaria immunity [22]. In the nearby suburbs, it has been found that $10 \%$ of delivering women were positive for Plasmodium parasites in the placenta and $44 \%$ of placentas showed chronic infection, associated with low birth weight [23].

\section{Malaria transmission in Dakar}

In this clinical context, local malaria transmission has been studied for several decades. In Pikine, a suburban area of Dakar, transmission was demonstrated in 197980 , with anopheline aggressiveness peaking at more than 100 Anopheles arabiensis bites per person per night (Plasmodium falciparum sporozoïte rate up to $1.14 \%$ ) and an Entomological Inoculation Rate (EIR) of 43 infective bites per person per year [24]. Less than 10 years later in the same city, An. arabiensis was still the main anopheline species captured but the estimated annual EIR did not exceed $0.382[14]$.

In the south and central sanitary districts of Dakar, in 1994-95 and 1996-97 respectively, An. arabiensis aggressiveness was low, with less than one bite per person per night and no infected Anopheles collected [17,25]. In 2005-2006, malaria transmission was assessed in two vegetated areas of downtown Dakar during the wintering periods; the recorded aggressiveness peak was close to 200 
bites per person per night and the EIR was up to 9.5 infective bites per year [26].

The results underline possible changes in the entomological situation in the Dakar region and suggest the need for larger entomological investigations, in order to assess the current malaria transmission risk in the area.

\section{Breeding sites}

Every Anopheles species has its preferred water bodies for oviposition, depending on climate, physical geography and human activities. Breeding sites can be natural or man-made, of various sizes, located in running or stagnant waters, shaded or sunny, permanent or temporary.

The main anopheline species found in the Cap-Vert peninsula are members of the Anopheles gambiae complex. Anopheles arabiensis is the major malaria vector and usually breeds in small, temporary, clear and shallow water, with small amounts of organic matter and surface vegetation [27]. In 2005, the following species were also found in Dakar [26]: Anopheles melas, a salt-water species, and one specimen of An. gambiae s.s.

In and around Dakar, temporary breeding sites can appear during the rainy season in tyres, step tracks, puddles, ditches and garbage cans, or in debris on construction sites. Anopheline larvae have also been sampled in permanent water collection sites, such as permanent swamps created by the rise of the water table, which are known locally as "niaye" [14], or permanent wells, called "céanes," that usually lack cemented walls and are used for the watering of market-gardens $[28,29]$.

To assess the heterogeneity of malaria transmission risk in Dakar, a clear understanding of current ecological requirements for the persistence of productive breeding habitats is necessary.

\section{Methods \\ Study site}

Dakar $\left(14^{\circ} 40^{\prime} 20^{\prime \prime}\right.$ North, $17^{\circ} 25^{\prime} 22^{\prime \prime}$ West), the capital city of Senegal, is located in the Cap-Vert peninsula at the westernmost point of Africa. The estimated population was 1,030,594 inhabitants in 2005, amounting to about $20 \%$ of the country's population. The population density is 12,233 inhabitants per $\mathrm{km}^{2}$. The altitude peaks at 104 $\mathrm{m}$ above sea level (Mamelles). The study was conducted in ten different areas of downtown Dakar and Pikine, one of its satellite city.

Site selection was done on the basis of a SPOT-5 (Satellite Pour l'Observation de la Terre) satellite image (CNES 2006, Distribution Spot Image SA) acquired in October 2006 (Figure 1) and classified using a supervised technique which allowed to affect each pixel of the image to a land cover. Result of this process provided a map of vegetation, water, bare soils and different types of urban areas. Based on this land cover map, the study areas were sampled in order to cover as many different environments as possible, in terms of type of urbanization and presence of vegetation. Each site was delimited on the ground to cover an area of about $200 \times 200 \mathrm{~m}$, depending on the technical and logistical limitations presented by the landscape (Figure 1). Geographic coordinates are given for the centre of each study area.

One study site was located in Pikine $\left(14^{\circ} 45^{\prime} 30^{\prime \prime} \mathrm{N}\right.$, $\left.17^{\circ} 23^{\prime} 56^{\prime \prime} \mathrm{W}\right)$, an underprivileged satellite city of Dakar. About half of the area is covered with marshland (locally called "niaye"), vegetation and market-gardens whose wells (locally called "céanes") are not reinforced with cement. In the remainder of this area, buildings are individual or collective, structured around a network of unpaved sand roads.

The other study sites were located in the city of Dakar. "Almadies" $\left(14^{\circ} 44^{\prime} 42^{\prime \prime} \mathrm{N}, 17^{\circ} 30^{\prime} 38^{\prime \prime} \mathrm{W}\right)$ is located in a privileged residential area. About half of the study area is covered with vegetation and a pond. In the other half, houses are big, air-conditioned and surrounded by large private gardens. The primary road network is paved and the secondary one is unpaved.

"Université" $\left(14^{\circ} 41^{\prime} 22^{\prime \prime} \mathrm{N}, 17^{\circ} 27^{\prime} 49^{\prime \prime} \mathrm{W}\right)$ is located on the campus of Dakar Université. Most of the area is covered with low vegetation, trees and a pond. The two existing buildings housing student dormitories are about $70 \mathrm{~m}$ long and 4-5 stories high and served by paved asphalt pathways.

"Hann Maristes" $\left(14^{\circ} 43^{\prime} 54^{\prime \prime} \mathrm{N}, 17^{\circ} 25^{\prime} 57^{\prime \prime} \mathrm{W}\right)$ is mostly covered by a large park with tall trees and a lake. Outside of the park, the recently-built collective high-rise buildings are spaced out and the road network consists of unpaved sand roads.

"Ouest Foire" $\left(14^{\circ} 44^{\prime} 41^{\prime \prime} \mathrm{N}, 17^{\circ} 28^{\prime} 17^{\prime \prime} \mathrm{W}\right)$, close to the airport, is half-covered with low-lying vegetation on sandy ground. On the other half of the site, there are individual houses or small collective buildings, new or under construction. The roads are unpaved. The centre of the area is located in a depression.

"Gibraltar" (14 $\left.{ }^{\circ} 41^{\prime} 3 " \mathrm{~N}, 17^{\circ} 26^{\prime} 41^{\prime \prime} \mathrm{W}\right)$ is in a well-urbanized area, the one closest to the city centre, with mediumsize collective buildings and asphalt roads. Vegetation is limited to some trees bordering the main roads.

"Yarakh" $\left(14^{\circ} 42^{\prime} 56^{\prime \prime} \mathrm{N}, 17^{\circ} 26^{\prime} 7^{\prime \prime} \mathrm{W}\right)$ was in an area consisting of spontaneous dwellings (huts) built near the railroad and surrounded by an industrial neighbourhood. 


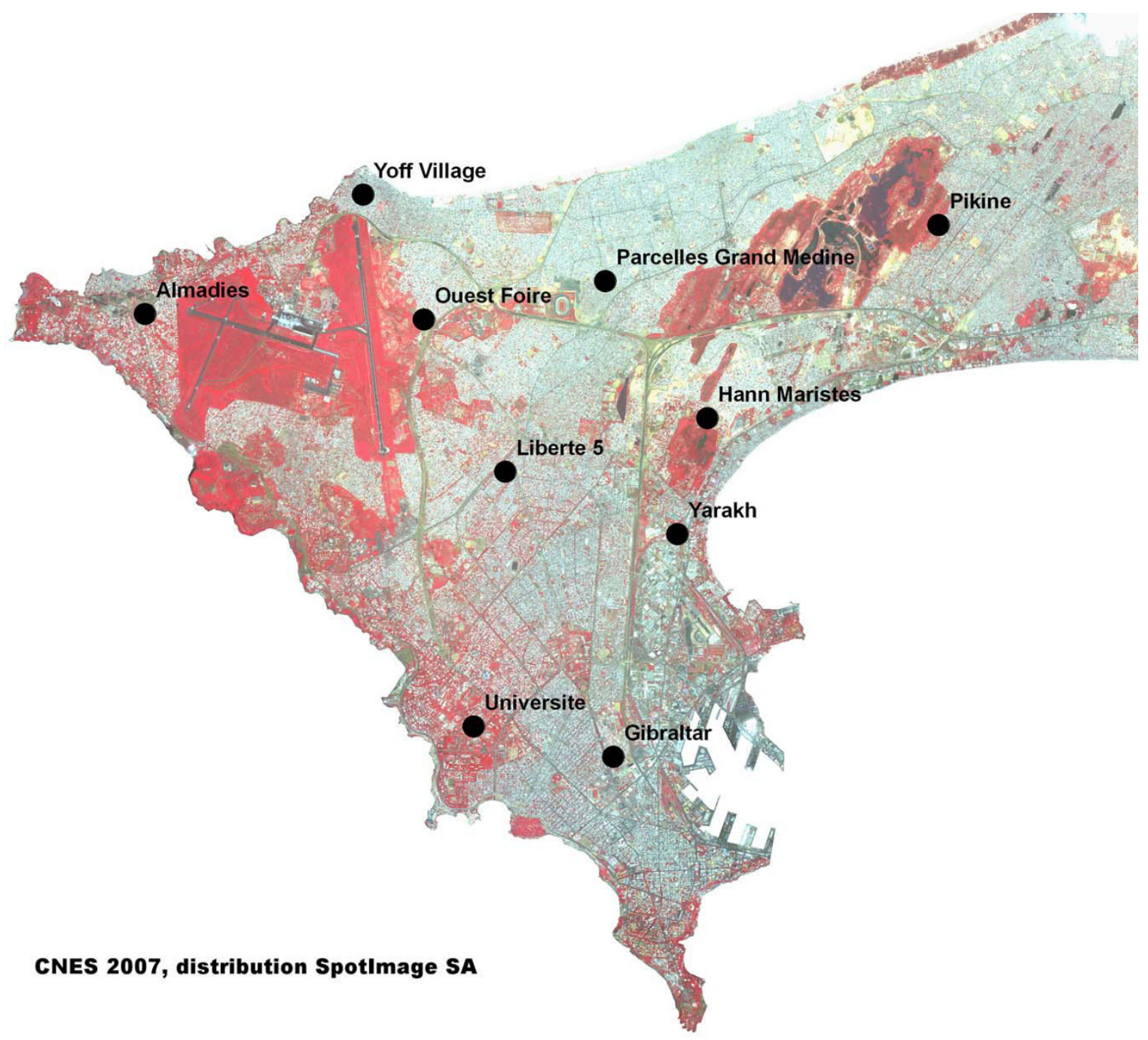

Figure I

Cap-Vert peninsula and localization of the ten study areas.

About half of the area was composed of market-gardens, watered using either "céanes" or cemented wells.

"Liberté $5^{\prime \prime}\left(14^{\circ} 43^{\prime} 23^{\prime \prime} \mathrm{N}, 17^{\circ} 27^{\prime} 36^{\prime \prime} \mathrm{W}\right)$ is in a well-urbanized residential area, with individual houses of medium size, sometimes with small private gardens. The road network is asphalted. Vegetation is limited to trees bordering main roads and inside the gardens.

Half of the "Parcelles Grand Medine" site $\left(14^{\circ} 44^{\prime} 58^{\prime \prime N}\right.$, $17^{\circ} 26^{\prime} 42^{\prime \prime} \mathrm{W}$ ) is located in a well-planned, urbanized area built on cleaned-up swamps. Individual and collective buildings have two or three storeys and roads are sandy. The other half of the site is in a crowded area, with very narrow sandy pathways. Individual houses are small, often with cemented yards. Nearly no vegetation was found in this part of the study area.
The "Yoff Village" site $\left(14^{\circ} 45^{\prime} 36^{\prime \prime} \mathrm{N}, 17^{\circ} 28^{\prime} 49^{\prime \prime} \mathrm{W}\right)$ is a former fisher village, urbanized with small individual and collective buildings of about two storeys, near the seashore. Roads are narrow and sandy. Nearly no vegetation was found in this study area.

\section{Climate and study period}

The Cap-Vert peninsula has a mild sahelian climate. The hot and wet season lasts from June to November, with average temperatures between 24 and $30^{\circ} \mathrm{C}$. The cool and dry season lasts from December to May, with average temperatures between 19 and $25^{\circ} \mathrm{C}$. The first rains generally occur at the end of June or the beginning of July, and the last ones at the beginning of October. In 2005, 2006 and 2007, the average annual rainfalls were 525, 350 and 248 $\mathrm{mm}$, respectively (data from the Tropical Rainfall Measuring Mission [TRMM] - NASA - http://trmm.gsfc.nasa.gov/ 
). As a majority of the rain falls in August and September, the study period was chosen to last from September through October 2007, in order to catch the peak of malaria transmission.

\section{Adult mosquito field sampling}

Adult mosquito sampling was carried out once every two weeks during the study period. Human landing catch of adult mosquitoes was conducted both indoors (one catching point) and outdoors (two catching points) in each of the ten study areas, for a total of four nights of capture in each place. Indoor captures were conducted with the window or door slightly ajar. The three catching points were located around the centre of each study area. Within each area, distance between each of the three catching point was about 30 meters. Collectors gave prior informed consent and received yellow fever immunizations and anti-malarial chemoprophylaxis consisting of $100 \mathrm{mg}$ doxycycline per day for the duration the study and one month thereafter. Two collectors were contracted for each catching point to work from 8:00 p.m. to 7:00 a.m., with each one resting every two hours. Collectors were rotated among the catching points on different collection nights to minimize sampling bias.

The mosquitoes were recorded by catching point, date and hour of capture and they were sorted by genera.

\section{Biting patterns and sporozoite rates}

The heads and thoraces of all adult anopheline females caught on human bait were tested by enzyme-linked immunosorbent assay (ELISA) to detect the presence of $P$. falciparum circumsporozoite protein (CSP) [30].

The human biting rate (HBR), also termed aggressiveness, was expressed as the number of female anopheline bites per person per night, averaged for both outdoor and indoor catching points. The CSP index was calculated as the proportion of mosquitoes positive for CSP. Differences between the CSP indices of the various study areas were tested using the Fisher exact test.

The entomological inoculation rate (EIR) was the product of the HBR and the CSP index of mosquitoes collected on humans. Data on seasonal transmission in sahelian climates [31] and previous results $[25,26]$ indicate that $A n$. gambiae s.l. biting activity is compatible with malaria transmission occurring only at the end of the rainy season. Consequently, the annual EIR was considered equivalent to the September-October EIR. Thus, annual EIR was calculated as the product of the EIR multiplied by 60 days.

\section{Adult mosquito species identification}

The anopheline mosquitoes were identified morphologically following the Gillies and Coetzee keys [27]. Culicinae were identified morphologically following the Edwards keys [32]. All anopheline mosquitoes were stored individually in numbered vials with desiccant and preserved at $20^{\circ} \mathrm{C}$ in the Medical Entomology Unit of the Institute for Tropical Medicine (IMTSSA), Marseille (France), until processing.

Depending on the number of Anopheles caught by site, all specimens or a random sample of a maximum of 100 specimens belonging to the An. gambiae complex were selected from each study site for identification to species by polymerase chain reaction (PCR) [33]. All CSP-positive anopheline mosquitoes were also tested. Differences in the distribution of species between the study areas were tested using the Fisher exact test.

\section{Field larval sampling}

Each yard within the study areas was searched for open water collection sites. The study areas were visited every week during the eight weeks of the study period, except for the "Université", "Hann Maristes" and "Gibraltar" areas, which were only monitored during the last six weeks of the study period. All the water collections in the ten study areas were examined for larvae. Larvae and pupae were sampled using a standard dipping method [34]. When anopheline specimens were found, larval density was calculated as the number of larvae (all instars) and pupae (further emerged and identified at the laboratory) per dip and recorded for each water collection site. Temporal synchronism in larval density was examined within each area to assess whether the peaks of larval density were synchronized across the breeding sites within each study area. The presence of Culicinae larvae was also recorded.

\section{Larval mosquito data analysis}

A random sample of the larvae and all the pupae were taken to the laboratory for growth and emergence. The neonate Anopheles were identified morphologically following the Gillies and Coetzee keys [27], stored by date and breeding site in numbered vials with desiccant and preserved at $-20^{\circ} \mathrm{C}$ at the Medical Entomology Unit of the Institute for Tropical Medicine (IMTSSA), Marseille (France), until processing.

All anopheline larvae that were collected in study areas where An. melas adults had been caught on human bait and that emerged in the laboratory were identified by species following the same PCR protocol.

\section{Characterization of open water collection sites}

Physical, biological and chemical characteristics of the open water collection sites were recorded by the same person, in order to maintain consistency in visual classifications.

Habitat type of all bodies of water were categorized as ditches or puddles, swamp areas, marshes, ponds or lakes, 
"céanes," cemented wells or basins, man-made water collection sites, waterproof containers or canals. A water collection site was considered temporary when it was found to be dry at least once during the follow-up or during one field visit undertaken at the end of the 2008 dry season, before the first rains. Otherwise, it was recorded as permanent.

Identification of predators was limited to all types of larvivorous fishes, such as guppies, Gambusia or Tilapia, which are larval predators. Larvivorous fishes were introduced in Dakar in the 1930s and their presence in marketgarden wells is recommended by the National Hygiene Service. Their presence was assessed visually.

The perimeter of each body of water was measured using a centimetre for small pools of water (perimeter $<5$ metres) and estimated using the number of strides (gauged at one metre each) for large bodies of water (perimeter $\geq 5$ metres). The area of each body of water was evaluated by approximating the shape as a square, a rectangle, a circle or an ellipse.

The temperature of the water was measured with a mercury-in-glass thermometer immerged for 60 seconds.

Turbidity was estimated by using a graduated transparent bottle with black letters written on the bottom. The bottle was filled with water from the collection site and turbidity was evaluated by the graduation that the water reached before the letters were no longer visible. Graduations ranged from 0 to $26 \mathrm{~cm}$, starting from the top of the bottle, so that a higher value indicated greater turbidity.

The proportion of the water surface covered by vegetation was estimated visually. The vegetation was not classified further, but included water lettuce, water lentils and grass.

The proportion of the water surface exposed to sunlight was estimated visually by assessing the proportion of the water surface shadowed at midday.

Because of recent reports of An. melas in Dakar [26], salinity was measured for a sub-sample of the observed water collection sites. Two drops of chloroform were added to water samples, which were then transported to the laboratory (Laboratoire des Moyens Analytiques, IRD Bel Air, Dakar) in a cool box containing ice, for analysis with a conductivity meter (Symphony ${ }^{\mathrm{TM}}$ SB70C, VWR International $^{\circledast}$ ) within hours after their collection.

\section{Statistical analysis}

The statistical analyses of the larval collections aimed to identify: 1) the determinants of the presence/absence of anopheline larvae in water collection sites, and 2) the fac- tors associated with the density of anopheline larvae in the breeding sites.

Continuous independent variables were dichotomized at the median. The statistical unit was the weekly measurement of variables for a given water collection site.

In longitudinal studies, some correlation could exist between observations made on the same water collection site. To take into account this interdependence of observations, GEE population-averaged models were used. The within-group correlation structure was chosen as autoregressive of order 1, corresponding to the one-week delay between two observations of the same site.

Similarities could exist between water collection sites in the same study area. Thus, a dummy variable corresponding to the study sites was forced in all univariate and multivariate analyses to take into account the fact that several water collection sites belonged to the same study area.

The presence/absence of larvae in the water collection sites was analysed using a logistic regression model. The larval density by breeding site was analysed using a negative binomial regression model. The dependant variable was the number of larvae per dip minus 1 , in order to overcome the exclusion of zero-values and take into account the number of dips sampled at each water collection site.

The variables associated with the presence or the density of larvae with a p-value $<0.25$ in univariate analysis were retained for multivariate analysis. A backward stepwise selection procedure was applied in the final model to keep variables with a p-value $<0.05$.

Adult densities were estimated at the study site level by the total number of Anopheles caught indoors and outdoors during one night of capture. The larval density index at each study site was estimated as follows. The product of the larval density multiplied by the estimated water surface was calculated for each breeding site within one week before the night of mosquito capture. The sum of these products over all the water collection sites was considered as the larval density index for the study area. Correlations between larval density index and adult densities were then examined for each study area. Correlations were also researched between raw larval densities and adult densities and between the estimated water surface and adult densities. All analyses were performed with STATA 9.0 (Stata-Corp LP).

\section{Results}

\section{Adult mosquito collection}

A total of 19,451 mosquitoes (74.18\% Culex quinquefasciatus, $15.47 \%$ Culex tritaeniorynchus, 5.66\% An. gambiae 
s.l., 4.22\% Aedes aegypti, 0.05\% Anopheles pharoensis) were caught during 120 person-nights of collection on human bait. A total of 1,101 An. gambiae s.l. were collected (Table 1).

\section{Biting behaviour of An. gambiae s.I}

The total number of An. gambiae s.l. caught during the 12 person-nights of collection in each of the study areas ranged from one in Yoff Village to 524 in Almadies (Table 2). Among the 1,101 An. gambiae s.l. caught on human collectors during the eight weeks of follow-up in the 10 study areas, 870 were caught outdoors (two catching points for each night of capture) and 231 were caught indoors (one catching point for each night of capture) (Table 2). Using the number of outdoor bites averaged for one catching point only, it has been found that $35 \%$ of all bites were received indoors. Considering all ten study areas together, the peak biting time was between 1:00 a.m. and 5:00 a.m. both outdoors (Figure 2a) and indoors (Figure 2b). Anopheles gambiae s.l. caught during this time range accounted for $65 \%$ and $61 \%$ of the total number caught outdoors and indoors, respectively, during the whole night.

\section{Molecular identification of An. gambiae s.l. caught on human bait}

Depending on the total number of specimens collected in each study area, the random sample selected for molecular identification of species represented $19 \%$ to $100 \%$ of the total adult An. gambiae s.l. caught. Among the 496 specimen tested by PCR, the An. gambiae complex population was composed of An. arabiensis (94.8\%) and An. melas (5.2\%). The detailed percentages of An. arabiensis and An. melas per study area are presented in Table 3. Differences among areas were significant (exact Fisher test; p $<0.001)$.

\section{HBR, CSP and EIR}

HBR was calculated as the number of Anopheles bites received per person per night, taking into account figures for both indoor and outdoor bites, averaged over the eight weeks of follow-up. An. gambiae s.l. HBR ranged from 0.1 bites per person per night in Yoff Village to 43.7 in Almadies. The highest recorded HBR was 211 bites per person per night, outdoors at the end of September in Almadies. The highest aggressiveness was recorded in the second half of September (Figure 3), when $42 \%$ of all adult An. gambiae s.l. were caught.

All of the 1,101 An. gambiae s.l. were processed by ELISA for $P$. falciparum antigen detection and seven were found to be positive. None of the An. melas were found to be infected with $P$. falciparum. The infected An. arabiensis. were caught outdoors in Almadies, Pikine, Ouest Foire and Yarakh, in September or in the first fortnight of October. The mean CSP index was 0.64\% (95\% CI $=0.19 \%-$ $0.96 \%)$. No significant differences were found in CSP indices between the study areas (exact Fisher test; $\mathrm{p}=$ 0.790). Thus, EIR, annual EIR and the calculated period (in days) between two An. arabiensis infective bites were calculated using the mean CSP index. Annual EIR ranged from 0 infective bites in Yoff Village to 16.8 in Almadies. HBR and EIR figures for An. arabiensis are presented in Table 4. Differences between An. arabiensis annual EIR and An. gambiae s.l. annual EIR were found mainly for Pikine were it decreased form 7.3 to 5.8 taking An. arabiensis HBR only.

\section{Larval sampling}

A total of 54 open bodies of water were monitored weekly, during four to eight weeks. Several types of open water collection sites were found: 23 ditches or puddles, seven swamp areas, marshes, ponds or lakes, 16 "céanes," cemented wells or basins, three man-made water collection sites, four waterproof containers and one canal.

Of the water collection sites, 34 (63\%) were temporary (23 ditches or puddles, four swamp areas, marshes, ponds or lakes, three man-made water collection sites and four waterproof containers) and 20 (37\%) were permanent

Table I: Distribution by genus and species of adult mosquitoes collected on humans in the ten study areas of Dakar in SeptemberOctober 2007; there were two outdoor catching points ( 80 person-nights collection) and one indoor catching point (40 person-nights collection) for each site.

\begin{tabular}{|c|c|c|c|c|c|}
\hline & $\begin{array}{r}\text { Outdoors } \\
\text { (2 catching points per study site) }\end{array}$ & $\begin{array}{r}\text { Indoors } \\
\text { (I catching point per study site) }\end{array}$ & $\%$ Indoors* & Total & $\%$ of total population \\
\hline Anopheles gambiae s.l. & 870 & 231 & $35 \%$ & 1101 & $5.7 \%$ \\
\hline Anopheles pharoensis & 9 & 1 & $18 \%$ & 10 & $0.05 \%$ \\
\hline Culex quinquefasciatus & 9393 & 5035 & $52 \%$ & 14428 & $74.2 \%$ \\
\hline Culex tritaeniorhynchus & 2606 & 404 & $24 \%$ & 3010 & $15.5 \%$ \\
\hline Aedes aegypti & 770 & 51 & $12 \%$ & 821 & $4.2 \%$ \\
\hline Aedes metallicus & 1 & 0 & $0 \%$ & I & $0.01 \%$ \\
\hline Mansonia sp & 62 & 18 & $37 \%$ & 80 & $0.4 \%$ \\
\hline Total & $137 \mid 1$ & 5740 & $42 \%$ & $1945 \mid$ & $100 \%$ \\
\hline
\end{tabular}

* Percentages of indoor bites were calculated using the number of outdoor bites averaged for one catching point. 
Table 2: Distribution of adult An. gambiae s.l. collected on humans in two outdoor catching points (8 person-nights collection per study site) and one indoor catching point (4 person-nights collection per study site) in the ten study areas of Dakar in September-October 2007.

\begin{tabular}{lrr}
\hline Study sites & $\begin{array}{r}\text { Outdoors } \\
\text { (2 catching points per study site) }\end{array}$ & $\begin{array}{r}\text { Indoors } \\
\text { (I catching point per study site) }\end{array}$ \\
\hline Almadies & 478 & 46 \\
Pikine & 150 & 524 \\
Université & 111 & 228 \\
Hann Maristes & 35 & 138 \\
Ouest Foire & 32 & 27 \\
Gibraltar & 24 & 29 \\
Yarakh & 31 & 17 \\
Liberté 5 & 64 & 49 \\
Parcelles Grand Medine & 2 & 43 \\
Yoff Village & 19 \\
\hline Total & 11 & 2 \\
\hline
\end{tabular}

(one canal, three swamp areas, marshes, ponds or lakes, 16 "céanes," cemented wells or basins). Most (79\%) of 34 temporary collection sites and many $(40 \%)$ out of 20 permanent collection sites were observed to be habitats for anopheline larvae at least once during follow-up.

More than half $(33,61.1 \%)$ of the bodies of water were found to be breeding sites for anophelines on at least one observation during the follow-up period but only six $(11.1 \%)$ harboured larvae for the whole duration of the follow-up. No breeding habitats were found in Liberté 5 and Yoff Village. In Parcelles Grand Medine, one breeding site was found outside of the $200 \times 200 \mathrm{~m}$ area. In the other study areas, the number of water collection sites ranged from four to eight. Most of the positive collection sites for mosquitoes were located in Almadies, where every body of water was observed to be a breeding site at least once during follow-up. In breeding habitats, the density of larvae and pupae ranged from 0.05 to 35 per dip (mean $=6.05,95 \% \mathrm{CI}=4.85-7.25)$.

No temporal synchronism was observed in the larval density of breeding sites within each area and the peaks in larval density were not synchronized within each study area.

\section{Identification of An. gambiae s.l. reared from larval samples}

Identification of species by PCR amplification showed that 388 adult An. gambiae s.l. specimens reared from larval samples were An. arabiensis. No An. melas mosquitoes were identified.

\section{Characterization of open water collections}

A total of 389 observations of water collection sites were recorded, among which $130(33.4 \%)$ were positive for Anopheles in immature stages (i.e,. larvae or pupae), 196
(50.4\%) were negative and $63(16.2 \%)$ corresponded to a water collection site that had dried up. The percentage of observations in which the water collection site had dried up increased from 0 to $31.5 \%$ over the course of followup. Only the 326 observations of sites containing water (and not the observations of dried-up sites) were taken into account in the following analysis.

Larvivorous fishes were found in 180 (62\%) observations of 42 water collection sites that were negative for larvae and pupae and $112(48 \%)$ observations of 36 water collection sites that were positive. Description of the quantitative physical, biological and chemical parameters recorded for the open bodies of water are presented in Table 5. Based on 99 observations, mean salinity was 1.34 $\mathrm{g} / \mathrm{l}(95 \% \mathrm{CI}=1.07-1.6])$ and ranged from 0 to $6.8 \mathrm{~g} / \mathrm{l}$.

\section{Determinants of the presencelabsence of larvae and larval density}

Three water collection sites were observed only once because they dried up after the first week of observation, although all three harboured larvae when they were observed. The 19 observations corresponding to these locations were excluded from the statistical analysis, as the fit of GEE models with an autoregressive correlation matrix required at least two observations of the same water collection site.

Thus, 323 observations with known breeding status and 123 observations of breeding sites with known larval density were considered for the following analysis.

Tables 6 and 7 provide the results of univariate analyses for the presence/absence of Anopheles larvae and larval density, respectively. The total number of observations may differ from the one in Table 5 because of the restric- 


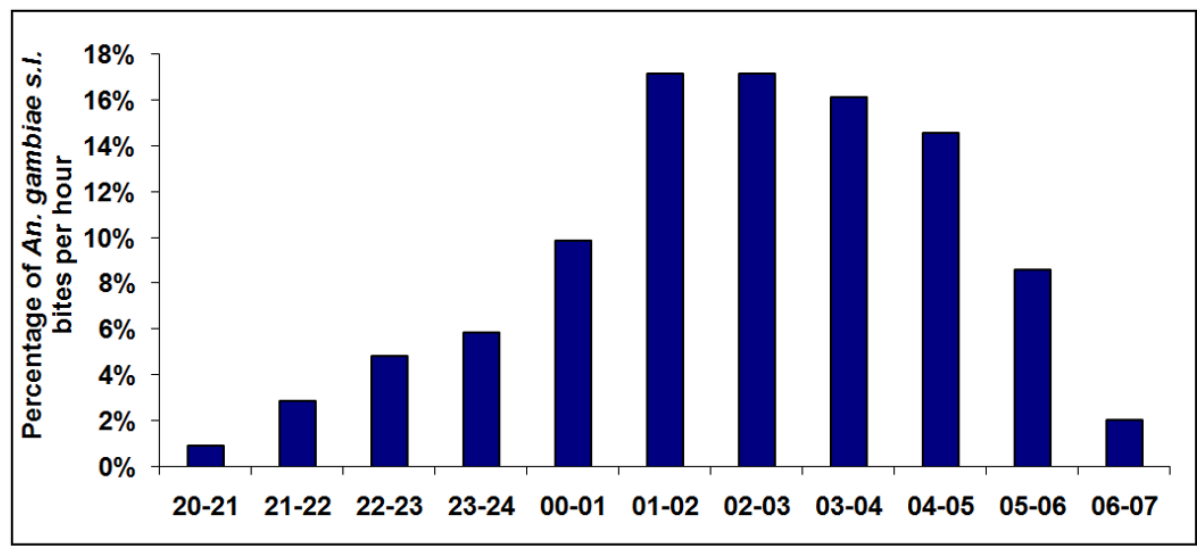

2a

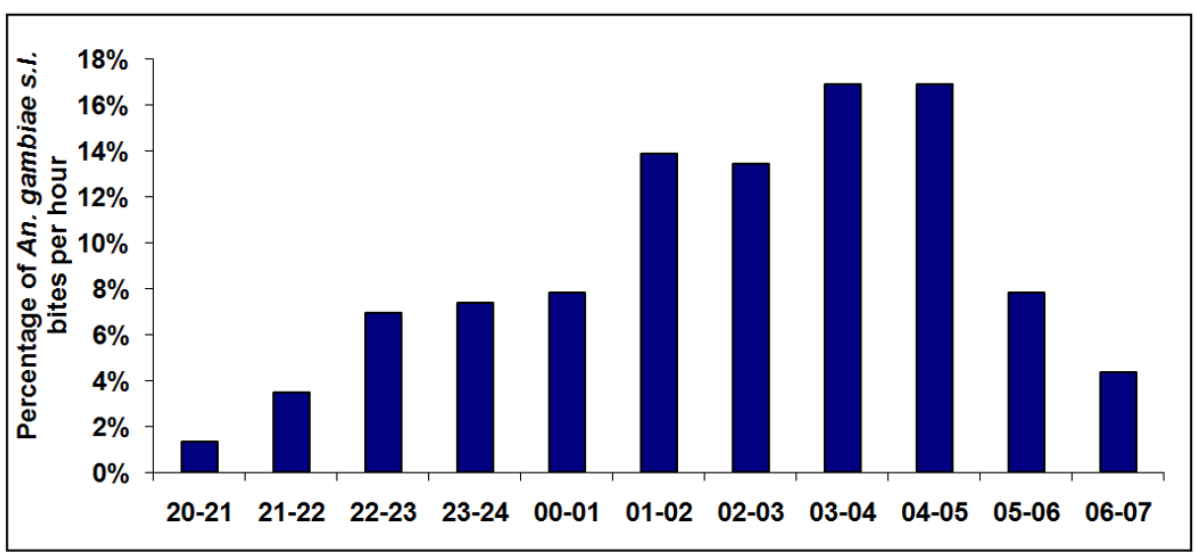

2b

Figure 2

Hourly distribution of An. gambiae s.I. bites outdoors (Figure 2a) and indoors (Figure 2b) in the ten study areas of Dakar in September-October 2007.

tion introduced by the fit of the GEE statistical model. Analyses for the presence/absence of Anopheles larvae were completed based on observations for which the larval status was known, even if the larval density was unrecorded. Thus, the total number of observations may differ between Tables 6 and 7 .

Table 8 provides the results of the multivariate analyses for the presence/absence of Anopheles larvae and for larval densities. Salinity was not included in the multivariate analysis because of the small number of observations for which this parameter was recorded.

Temporary nature, habitat type, perimeter, water temperature, percentage of surface vegetation and co-occurrence of Culicinae larvae were significantly associated with the presence/absence of larvae in bivariate analysis (taking into account the study area effect). The only variables remaining in the model after applying the backward step- wise selection were the presence of Culicinae larvae, the habitat type and the study area.

Larval density was significantly associated with habitat type, water temperature, percentage of surface vegetation and co-occurrence of Culicinae larvae in bivariate analysis (taking into account the study area effect). These four parameters remained significant in the multivariate analysis.

\section{Correlation between larval and adult densities}

Figure 4 shows the temporal variations in adult density and larval density index the week before the adult captures, in the study districts for which the larval and adult densities were high enough for comparison. Liberté 5, Parcelles Grand Medine and Yoff Village are not represented, as no breeding sites were found within the $200 \times$ $200 \mathrm{~m}$ study area. In Université, Hann Maristes and Gibraltar, only three values are available for larval density 
Table 3: Proportions of An. arabiensis and An. melas among the An. gambiae s.l. collected on humans in the ten study areas of Dakar in September-October 2007.

\begin{tabular}{|c|c|c|c|c|c|}
\hline & $\begin{array}{l}\text { Number of An. gambiae } \\
\text { s.l. processed by PCR }\end{array}$ & $\begin{array}{r}\text { Number of An. } \\
\text { arabiensis }\end{array}$ & $\begin{array}{r}\text { Proportion of An. } \\
\text { arabiensis }\end{array}$ & Number of An. melas & $\begin{array}{r}\text { Proportion of An. } \\
\text { melas }\end{array}$ \\
\hline Almadies & 102 & 102 & $100 \%$ & 0 & $0 \%$ \\
\hline Pikine & 99 & 78 & $79 \%$ & 21 & $21 \%$ \\
\hline Université & 93 & 93 & $100 \%$ & 0 & $0 \%$ \\
\hline Hann Maristes & 62 & 58 & $94 \%$ & 4 & $6 \%$ \\
\hline Ouest Foire & 44 & 44 & $100 \%$ & 0 & $0 \%$ \\
\hline Gibraltar & 43 & 43 & $100 \%$ & 0 & $0 \%$ \\
\hline Yarakh & $4 I$ & 41 & $100 \%$ & 0 & $0 \%$ \\
\hline Liberté 5 & 7 & 7 & $100 \%$ & 0 & $0 \%$ \\
\hline $\begin{array}{l}\text { Parcelles Grand } \\
\text { Medine }\end{array}$ & 4 & 3 & $75 \%$ & 1 & $25 \%$ \\
\hline Yoff Village & I & I & $100 \%$ & 0 & $0 \%$ \\
\hline Total & 496 & 470 & $95 \%$ & 26 & $5 \%$ \\
\hline
\end{tabular}

because the follow-up lasted six weeks. In Pikine and Ouest Foire, one value for larval density was missing.

The graphical examination highlights a very close parallel between larval and adult densities in six out of seven study areas. Graphical comparisons of the temporal variations of the adult density with the raw larval density on one hand and the surfaces of the water collections on the other hand did not show this close parallel.

\section{Discussion}

\section{Heterogeneity in local malaria transmission}

The results provide evidence of malaria transmission in downtown Dakar and its nearby suburb. The rate of infection of the An. gambiae s.l. caught on human bait at the end of the 2007 rainy season was $0.64 \%$.

Spatial heterogeneity of human biting rates was very marked, with HBR up to 400 times higher in one area than in other areas located a few kilometres away. HBR ranged from 0.1 bites per person per night in Yoff Village to 43.7 in Almadies. Heterogeneity of the CSP index could not be demonstrated, as no significant differences were found in the rates of infection among the study areas. Nevertheless, the high heterogeneity in anopheline aggressiveness led to a high heterogeneity in the risk of malaria transmission between inhabitants of different study areas. Annual EIR could be calculated using the figures for September and October, as the majority of Anopheles bites are received during this period of the year $[25,26]$. EIR ranged from 0 infective bites per person per year in Yoff Village to 16.8 in Almadies (one infective bite every four days during the transmission season). Thus, in Dakar, no mean figures for transmission would provide a comprehensive picture of the situation; risk evaluations should be conducted on a local scale.

The highest HBR (43.7) and the highest annual EIR (16.8) of the present study were recorded in Almadies. In one of the outdoor catching points, the HBR reached 211 bites

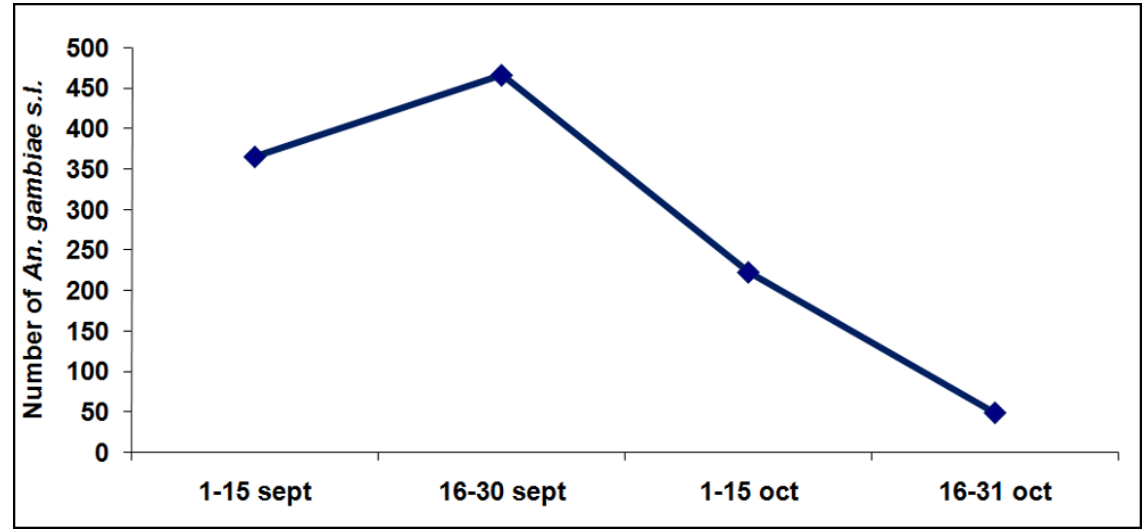

Figure 3

Temporal distribution of adult An. gambiae s.l. collected in two catching points outdoors and one catching point indoors in the ten study areas of Dakar in September-October 2007. 
Table 4: HBR, EIR, annual EIR and calculated period in days (I/EIR) between two infected bites by An. Arabiensis in the ten study areas of Dakar in September-October 2007 (mean CSP index $=0.64 \%$ ).

\begin{tabular}{lrrrr}
\hline Zone & HBR & EIR & Annual EIR & Calculated period (in days) between 2 infected bites \\
\hline Almadies* & 43.7 & 0.28 & 16.8 & 4 \\
Pikine * & 15.0 & 0.10 & 5.8 & 10 \\
Université & 11.5 & 0.07 & 4.4 & 14 \\
Hann Maristes & 5.0 & 0.03 & 1.9 & 31 \\
Ouest Foire $*$ & 4.1 & 0.03 & 1.6 & 38 \\
Gibraltar & 3.6 & 0.02 & 1.4 & 43 \\
Yarakh * & 3.5 & 0.02 & 1.3 & 45 \\
Liberté 5 & 0.7 & 0.00 & 0.3 & 223 \\
Parcelles Grand Medine & 0.2 & 0.00 & 0.1 & 694 \\
Yoff Village & 0.1 & 0.00 & 0.0 & 1563 \\
\hline
\end{tabular}

* Study areas in which infected Anopheles have been caught.

per person in one night at the end of September. This high HBR could be explained by the large number of productive breeding sites found in this study area, and the high density of larvae in these habitats. The large amount of vegetation in this area could also favour the survival of adult mosquitoes. Furthermore, the population density in the area was low and the type of housing in this privileged residential area meant that most of the population slept in air-conditioned rooms, which could lead to a concentra- tion of bites on the few night watchmen sleeping outdoors.

Annual An. arabiensis EIRs in Pikine, Université, Hann Maristes and Ouest Foire ranged from 1.6 to 5.8 and were consistent with the results of the meta-analysis by Robert et al [3], which showed that mean annual EIR was 7.1 in sub-Saharan African city centres and that more than twothirds of the studies reported an EIR $<4$ infective bites per

Table 5: Description of the quantitative physical, biological and chemical parameters recorded for the open water collection sites in the ten study areas of Dakar, depending on breeding status.

\begin{tabular}{|c|c|c|c|}
\hline Parameters & & Anopheline larvae and pupae absent & Anopheline larvae and pupae present \\
\hline \multirow[t]{5}{*}{ Perimeter (metres) } & $\mathrm{n}$ collection sites $=54$ & 43 & 36 \\
\hline & n observations $=326$ & 196 & 130 \\
\hline & Range & $0.3-579.3$ & $0.4-1973.6$ \\
\hline & Mean and $95 \% \mathrm{Cl}$ & $36.3[26.0-46.7]$ & $148.4[76.6-220.2]$ \\
\hline & 25-50-75 percentiles & $6.3-16.7-39.5$ & $9.8-29.7-75.6$ \\
\hline \multirow[t]{5}{*}{ Temperature $\left({ }^{\circ} \mathrm{C}\right)$} & $\mathrm{n}$ collection sites $=54$ & 40 & 34 \\
\hline & n observations $=248$ & 152 & 96 \\
\hline & Range & $25.0-39.0$ & $25-40$ \\
\hline & Mean and $95 \% \mathrm{Cl}$ & $29.5[29.1-29.9]$ & $31.7[30.9-32.5]$ \\
\hline & 25-50-75 percentiles & $28-29-30$ & $28-31-34$ \\
\hline \multirow[t]{5}{*}{ Turbidity } & $\mathrm{n}$ collection sites $=54$ & 35 & 31 \\
\hline & n observations $=225$ & 135 & 90 \\
\hline & Range & $0-26$ & $0-26$ \\
\hline & Mean and $95 \% \mathrm{Cl}$ & $9[7-10]$ & $16[14-17]$ \\
\hline & 25-50-75 percentiles & $0-4-17$ & $8-19-23$ \\
\hline \multirow[t]{5}{*}{ Surface vegetation (\%) } & $\mathrm{n}$ collection sites $=54$ & 43 & 36 \\
\hline & n observations $=324$ & 194 & 130 \\
\hline & Range & $0-100$ & $0-90$ \\
\hline & Mean and $95 \% \mathrm{Cl}$ & $32[27-36]$ & $18[13-22]$ \\
\hline & 25-50-75 percentiles & $2-10-60$ & $0-5-20$ \\
\hline \multirow{5}{*}{ Sunlight (\%) } & $\mathrm{n}$ collection sites $=54$ & 42 & 34 \\
\hline & $\mathrm{n}$ observations $=319$ & 193 & 126 \\
\hline & Range & $0-100$ & $0-100$ \\
\hline & Mean and $95 \% \mathrm{Cl}$ & 63 [59-67] & 69 [64-74] \\
\hline & 25-50-75 percentiles & $50-70-95$ & $50-70-100$ \\
\hline
\end{tabular}


Table 6: Factors related to the presence/absence of anopheline larvae.



\section{Habitat type}

"Céanes", cemented weels or basins

Man-made water collections

Canals

Waterproof containers

Swamp areas, marshes, ponds or lakes

Ditches or puddles

128
18
8
15
44
110

\begin{tabular}{rrrrr}
5 & $4 \%$ & 1 & & $<0.001$ \\
5 & $28 \%$ & 2.45 & $0.29-20.83$ & 0.412 \\
4 & $50 \%$ & 3.02 & $0.21-43.62$ & 0.417 \\
6 & $40 \%$ & 4.43 & $0.48-40.62$ & 0.188 \\
24 & $55 \%$ & 7.82 & $1.40-43.73$ & 0.019 \\
84 & $76 \%$ & 24.82 & $4.63-130.82$ & $<0.001$ \\
\hline
\end{tabular}

\begin{tabular}{|c|c|c|c|c|c|c|}
\hline $\begin{array}{l}\text { Period } \\
\text { Weeks I - } 4 \\
\text { Weeks } 5-8\end{array}$ & $\begin{array}{l}162 \\
161\end{array}$ & $\begin{array}{l}62 \\
66\end{array}$ & $\begin{array}{l}38 \% \\
41 \%\end{array}$ & $\begin{array}{r}1 \\
1.09\end{array}$ & $0.58-2.03$ & 0.793 \\
\hline $\begin{array}{l}\text { Temporary collection } \\
\text { No } \\
\text { Yes }\end{array}$ & $\begin{array}{l}155 \\
168\end{array}$ & $\begin{array}{r}22 \\
106\end{array}$ & $\begin{array}{l}14 \% \\
63 \%\end{array}$ & $\begin{array}{r}1 \\
2.67\end{array}$ & $0.97-7.37$ & 0.058 \\
\hline $\begin{array}{l}\text { Perimeter (metres) } \\
<20 \mathrm{~m} \\
>=20 \mathrm{~m}\end{array}$ & $\begin{array}{l}157 \\
166\end{array}$ & $\begin{array}{l}54 \\
74\end{array}$ & $\begin{array}{l}34 \% \\
45 \%\end{array}$ & $\begin{array}{r}\text { I } \\
0.59\end{array}$ & $0.27-1.25$ & 0.168 \\
\hline $\begin{array}{l}\text { Water temperature }(n=243) \\
\angle 30^{\circ} \mathrm{C} \\
>=30^{\circ} \mathrm{C}\end{array}$ & $\begin{array}{l}120 \\
123\end{array}$ & $\begin{array}{l}31 \\
62\end{array}$ & $\begin{array}{l}26 \% \\
50 \%\end{array}$ & $\begin{array}{r}1 \\
1.96\end{array}$ & $0.93-4.13$ & 0.077 \\
\hline $\begin{array}{l}\text { Turbidity }(\mathbf{n}=\mathbf{2 2 2}) \\
<13 \text { (clear) } \\
>=13 \text { (turbid) }\end{array}$ & $\begin{array}{l}106 \\
116\end{array}$ & $\begin{array}{l}26 \\
62\end{array}$ & $\begin{array}{l}25 \% \\
53 \%\end{array}$ & $\begin{array}{r}1 \\
1.09\end{array}$ & $0.54-2.21$ & 0.808 \\
\hline $\begin{array}{l}\text { Surface vegetation }(\%, n=320) \\
<20 \% \\
>=20 \%\end{array}$ & $\begin{array}{l}195 \\
125\end{array}$ & $\begin{array}{l}93 \\
35\end{array}$ & $\begin{array}{l}48 \% \\
28 \%\end{array}$ & $\begin{array}{r}\text { I } \\
0.44\end{array}$ & $0.18-1.10$ & 0.078 \\
\hline $\begin{array}{l}\text { Sunlight }(\%, n=3 \mid 7) \\
<80 \% \\
>=80 \%\end{array}$ & $\begin{array}{l}202 \\
115\end{array}$ & $\begin{array}{l}73 \\
52\end{array}$ & $\begin{array}{l}36 \% \\
45 \%\end{array}$ & $\begin{array}{r}1 \\
0.99\end{array}$ & $0.40-2.45$ & 0.974 \\
\hline $\begin{array}{l}\text { Presence of predator }(\mathbf{n}=\mathbf{2 8 7}) \\
\text { No } \\
\text { Yes }\end{array}$ & $\begin{array}{l}132 \\
155\end{array}$ & $\begin{array}{l}55 \\
54\end{array}$ & $\begin{array}{l}42 \% \\
35 \%\end{array}$ & $\begin{array}{r}\text { I } \\
0.84\end{array}$ & $0.4 I-1.74$ & $0.64 I$ \\
\hline $\begin{array}{l}\text { Presence of Culicinae larvae } \\
(n=293) \\
\text { No } \\
\text { Yes }\end{array}$ & $\begin{array}{r}211 \\
84\end{array}$ & $\begin{array}{l}48 \\
58\end{array}$ & $\begin{array}{l}23 \% \\
69 \%\end{array}$ & $\begin{array}{r}\text { I } \\
5.46\end{array}$ & $2.55-11.66$ & $<0.001$ \\
\hline
\end{tabular}

Adjusted (by study area) odds ratio (OR) estimated by GEE logistic regression model. Bivariate analysis: 323 observations of water collection sites unless otherwise indicated.

* Water collections found outside of the $200 \times 200$ m study area 
year. In those areas, figures were also consistent with measurements conducted in two areas of Dakar in 20052006, which found EIRs of 3 to 9.5 infective bites per person per year [26]. Breeding habitats were found in these four areas and the large amount of vegetation may have favoured adult mosquito survival.

In Gibraltar, the annual EIR was 1.4 but none of the small water collection sites of the area provided a breeding habitat for more than one week during follow-up. Moreover, Gibraltar is a well-urbanized area with very little vegetation, which is probably not favourable for adult mosquito longevity. Extended investigations are needed to detect the breeding sites of the adult Anopheles caught on human bait in this area.

The annual EIR was 1.3 in Yarakh, but few breeding sites were located within the study area. The lack of a parallel between adult aggressiveness and the larval densities in this setting also suggests that the adult mosquitoes caught in this study area had their breeding site in the neighbourhood. The large amount of vegetation in the area also probably favoured the survival of adult mosquitoes.

In Liberté 5, Parcelles Grand Medine and Yoff Village, annual EIRs were below one infective bite per person per year. No infected specimens where caught in these areas, but even when applying the mean CSP index, the EIR was not compatible with transmission due to the low aggressiveness. Although no breeding sites were detected in Liberté 5, HBR was not nil. This could be explained by the presence of trees bordering the main roads and inside the gardens, which could constitute resting sites for adult Anopheles coming from sources located outside the study perimeter.

In Parcelles Grand Medine and Yoff Village, the EIR was close to zero. No breeding sites were detected in the $200 \times$ $200 \mathrm{~m}$ area and vegetation was very sparse, consistent with the very small number of specimens caught on human bait.

In an ecological point of view, areas where the presence of vegetation was important showed the highest vector densities (ex: Almadies, Pikine), favouring the presence of larval habitats and probably of resting places. On the contrary, areas where percentage of urbanization was high showed a lower number of adult Anopheles. Type of soil also had an importance as sand and asphalt (ex: Parcelles Grand Medine and Yoff Village) did not favour persistence of water, compared to mud and swamp areas (ex: Almadies and Yoff).

Among the ten study areas, four (Université, Liberté 5, Gibraltar, Yarakh) were located close to the areas studied by Diallo et al in 1994-95 and 1996-97 [17,25]. The HBRs measured in the present study were higher than those recorded during those past studies. This difference must be interpreted with caution, as the sites of mosquito captures were not exactly identical. Furthermore, the peak of An. gambiae s.l. aggressiveness lasts for little longer than one month, with a monthly frequency of capture, the previous studies could have missed this peak. The previously published results did not show any infected Anopheles, whereas the present study shows that transmission exists.

Transmission was demonstrated in Pikine 30 years ago $[14,24]$ and the present study provides new evidence of local transmission (annual EIR $=5.8$ ) at an intermediate level compared to the results published in 1979-80 (annual EIR = 43) and 1987-88 (annual EIR = 0.38).

Malaria transmission has not been recently studied in the other study areas of the project, so the present study provides new entomological data for Dakar's districts.

\section{Endo/exophagic behaviour}

Important differences existed between the study areas in terms of the endo/exophagic behaviour of An. gambiae s.l. but results should be interpreted carefully. Large differences were recorded between outdoor catching sites in the same study area during the same night. As logistical constraints limited the number of indoor catching points to one per site, the experimental design probably did not allow for results representative of adult An. gambiae s.l. behaviour in each study area. Using more outdoor and indoor catching points would allow for representative estimates of HBRs in each study site.

\section{Anopheline species}

Among the total female mosquitoes caught on human bait, 5.71\% were Anopheles (5.66\% An. gambiae s.l., and $0.05 \%$ An. pharoensis). This percentage was higher than that recorded in 1994-95 in the south district of Dakar, where the percentage of Anopheles was $0.7 \%$ [25], and in 1996-97 in the central district, where this proportion was $1.5 \%$ [17]. In Pikine in 1987-88, this percentage rose to more than $20 \%$ when collections were done on human bait [14].

In the present study, An. arabiensis and An. melas were the only representatives of the An. gambiae complex caught on human bait. No An. gambiae s.s. was found, as had been the case in Dakar in 2005-2006 [26]. Anopheles arabiensis was the main species identified during September and October 2007 and it accounted for $94.2 \%$ of the An. gambiae s.l. caught. Plasmodium falciparum infection was detected only in An. arabiensis specimens. The predominance of An. arabiensis was consistent with previous results from the Cap-Vert peninsula $[14,24,25,35]$. 
Table 7: Factors related to anopheline larval density.

\begin{tabular}{|c|c|c|c|c|c|c|c|}
\hline Habitat characteristics & Number of obs. & Number of dips & $\begin{array}{l}\text { Total number of } \\
\text { anopheline larvae }\end{array}$ & $\begin{array}{r}\text { Anopheline larval } \\
\text { density } \\
\text { (per dip) }\end{array}$ & $\mathrm{RR}$ & $95 \% \mathrm{Cl}$ & $\mathrm{P}$-value \\
\hline Zone & & & & & & & 0.028 \\
\hline Hann Maristes & 18 & 209 & 208 & 1.00 & ref. & & \\
\hline Pikine & 27 & 140 & 357 & 2.55 & 1.66 & $0.77-3.60$ & 0.198 \\
\hline Université & 14 & 54 & 246 & 4.56 & 2.23 & $0.91-5.46$ & 0.080 \\
\hline Yarakh & 2 & 18 & 110 & 6.11 & 2.28 & $0.41-12.76$ & 0.348 \\
\hline Ouest Foire & 22 & 93 & 578 & 6.22 & 3.09 & $1.38-6.95$ & 0.006 \\
\hline Almadies & 38 & 179 & 1309 & 7.31 & 4.09 & $1.98-8.45$ & $<0.001$ \\
\hline Gibraltar & 2 & 9 & 160 & 17.78 & 8.10 & $1.48-44.39$ & 0.016 \\
\hline Parcelles Grand Medine * & 0 & - & - & - & & & \\
\hline Liberté 5 & 0 & - & - & - & & & \\
\hline Yoff Village & 0 & - & - & - & & & \\
\hline
\end{tabular}

\section{Habitat type}

"Céanes", cemented weels or basins

Waterproof containers

Swamp areas, marshes, ponds or lakes

Ditches or puddles

Man-made water

collections

Canals

$\begin{array}{rr}8 & 53 \\ 5 & 17 \\ 22 & 116 \\ 80 & 488 \\ 4 & 16 \\ 4 & 12\end{array}$

53

17

116

488

16

12

126
30
467
2137
82
126

126
$<0.001$

2.38 ref.

$\begin{array}{llll}1.76 & 2.56 & 0.45-14.72 & 0.291\end{array}$

$\begin{array}{llll}4.03 & 14.76 \quad 3.76-57.88 & <0.001\end{array}$

$\begin{array}{llll}4.38 & 15.96 & 4.44-57.36 & <0.001\end{array}$

$\begin{array}{llll}5.13 & 17.45 & 2.62-116.14 & 0.003\end{array}$

$10.50 \quad 22.50 \quad 3.90-129.71<0.001$

\begin{tabular}{|c|c|c|c|c|c|c|c|}
\hline Period & & & & & & & 0.762 \\
\hline Weeks I - 4 & 57 & 328 & 1775 & 5.41 & ref. & & \\
\hline Weeks 5-8 & 66 & 374 & 1193 & 3.19 & 0.94 & $0.63-1.40$ & \\
\hline Temporary collection & & & & & & & 0.292 \\
\hline No & 23 & 134 & 379 & 2.83 & ref. & & \\
\hline Yes & 100 & 568 & 2589 & 4.56 & 1.44 & $0.73-2.85$ & \\
\hline Perimeter (metres) & & & & & & & 0.755 \\
\hline$<20 m$ & 49 & 226 & 1078 & 4.77 & ref. & & \\
\hline$>=20 \mathrm{~m}$ & 74 & 476 & 1890 & 3.97 & 0.93 & $0.59-1.46$ & \\
\hline $\begin{array}{l}\text { Water temperature } \\
(n=93)\end{array}$ & & & & & & & $<0.001$ \\
\hline$<30^{\circ} \mathrm{C}$ & 33 & 228 & 475 & 2.08 & ref. & & \\
\hline$>=30^{\circ} \mathrm{C}$ & 60 & 307 & 1611 & 5.25 & 3.34 & $1.97-5.68$ & \\
\hline Turbidity $(n=88)$ & & & & & & & 0.592 \\
\hline$<13$ (clear) & 28 & 142 & 700 & 4.93 & ref. & & \\
\hline$>=13$ (turbid) & 60 & 392 & $|26|$ & 3.22 & 0.87 & $0.52-1.46$ & \\
\hline Surface vegetation (\%) & & & & & & & 0.001 \\
\hline$<20 \%$ & 89 & 504 & 2596 & 5.15 & ref. & & \\
\hline$>=20 \%$ & 34 & 198 & 372 & 1.88 & 0.41 & $0.24-0.70$ & \\
\hline Sunlight $(\%, n=120)$ & & & & & & & 0.674 \\
\hline$<80 \%$ & 72 & 447 & 1194 & 2.67 & ref. & & \\
\hline$>=80 \%$ & 48 & 244 & 1665 & 6.82 & 1.13 & $0.64-2.00$ & \\
\hline
\end{tabular}


Table 7: Factors related to anopheline larval density. (Continued)

\begin{tabular}{|c|c|c|c|c|c|c|c|}
\hline $\begin{array}{l}\text { Presence of } \\
\text { predator }(n=104)\end{array}$ & & & & & & & 0.865 \\
\hline No & 48 & 308 & 1326 & 4.31 & ref. & & \\
\hline Yes & 56 & 286 & 1245 & 4.35 & 0.96 & $0.59-1.56$ & \\
\hline $\begin{array}{l}\text { Presence of Culicinae } \\
\text { larvae }(n=106)\end{array}$ & & & & & & & 0.016 \\
\hline No & 51 & 291 & 1259 & 4.33 & ref. & & \\
\hline Yes & 55 & 321 & 1033 & 3.22 & 1.71 & $1.10-2.64$ & \\
\hline
\end{tabular}

Adjusted (by study area) risk ratio (RR) estimated by GEE negative binomial regression model. Bivariate analysis; 123 observations of anopheline breeding sites, unless otherwise indicated.

* Water collections found outside of the $200 \times 200 \mathrm{~m}$ study area

In 1979-80, in Pikine, one An. melas was caught out of 92 An. gambiae s.l. adult females [24]. Anopheles melas was then captured for the first time in downtown Dakar in 2005-2006 and accounted for 2\% of the An. gambiae s.l. population [26]. In the present study, the percentage of An. melas was $5.2 \%$ on average, and the peak was greater than $20 \%$ in Pikine. As it is known that An. melas is not as good a vector as An. arabiensis [36], the relationship between aggressiveness and related malaria transmission risk must be interpreted carefully. This relationship will depend on the proportion of An. melas and also on the geographic areas. In the present study area of Pikine, the annual EIR calculated on An. gambiae s.l. aggressiveness was 7.3 infective bites, but the EIR calculated on An. arabiensis aggressiveness was only 5.8 infective bites.

In the breeding habitats, classification down to the species level of the sampled anopheline larvae identified only An. arabiensis. The places where An. melas were caught were those closest to the large marshy area locally called "niaye." In this area close to the Atlantic Ocean, the water table is high. In the eighties, Vercruysse et al [24] noted that this water table in Pikine was not brackish and that the first salty water collections were observed more than $10 \mathrm{~km}$ away from the study's capture points. Thirty years later, the situation could have changed so that the water table now provides habitats for An. melas larvae.

However, no An. melas larvae were found in the breeding sites we surveyed. There is no report in the literature of $A n$. melas larval habitats in Dakar or Pikine. Tolerance of An. melas larvae for salinity ranges from 5 to $37 \mathrm{~g} / \mathrm{l}$ [37]. The maximum salinity recorded in the present study was $6.8 \mathrm{~g} /$ 1, which would have been favourable for An. melas breeding. Further investigations are needed to detect larval habitats that might have been located outside of the present study areas.

Anopheles pharoensis accounted for only $0.05 \%$ of the total anopheline population and were captured mainly in Hann Maristes. Anopheles pharoensis had comprised 4\% of the adult anopheline population in Pikine in 1979-80 [24] but only one specimen was caught in the present study in 2007, perhaps indicating a change in the mosquito population. Even though An. pharoensis has been suggested as a significant vector in the Senegal River basin [38], it is generally not of epidemiological significance as a malaria vector in Senegal [39]. The low density measured in the present study confirms this fact in the capital.

Anopheles ziemanni was previously caught on human bait in Senegal, but in very low numbers [40]. In the present study, no adult specimens were caught on human bait. Anopheles ziemanni larvae have already been reported in Pikine [24] and accounted for 14\% of the sampled immature stage mosquitoes in the céanes of Dakar [28]. In the present study, no An. ziemanni was found among the sampled anopheline larvae. The population of An. ziemanni could have changed but the malaria risk would not be affected, as the human blood index of this species'is usually low and it is known only as a secondary or incidental vector [27].

\section{Larval habitats}

Among the 54 water collection sites monitored during the present study, several factors were found to be associated with the occurrence and abundance of anopheline larvae. The presence of larvae and the larval density were strongly associated with the study areas, demonstrating high spatial heterogeneity. This was consistent with the selection of the study areas, which aimed to cover maximal ecological diversity. Thus, adjusting further statistical models for the study area would make it possible to take into account factors that were not measured in the water collection sites but that could be related to their geographical localization.

In bivariate analysis, a higher probability of presence of anopheline larvae was found for water collection sites that were temporary and those with perimeter $<20 \mathrm{~m}$, with surface vegetation covering less than $20 \%$ of the total area, with a temperature $>=30^{\circ} \mathrm{C}$, or with a co-occurrence of Culicinae larvae. Anopheline larvae were also mainly found in ditches, puddles (all of them being temporary) and swamps, ponds or lakes (about half of them being temporary), highlighting the importance of temporary 
Table 8: Factors related to the presence/absence of larvae and larval densities, adjusted by study area.

\begin{tabular}{|c|c|c|c|}
\hline \multicolumn{4}{|c|}{ Presence/absence of anopheline larvae $(n=293)$, GEE logistic regression model } \\
\hline Habitat characteristics & Odds Ratio & $95 \% \mathrm{Cl}$ & $\mathrm{P}$-value \\
\hline & & & $<0.001$ \\
\hline \multicolumn{4}{|l|}{ Study areas } \\
\hline Pikine & 1.96 & $0.08-49.21$ & 0.682 \\
\hline Yarakh & 2.10 & $0.05-93.07$ & 0.702 \\
\hline Hann Maristes & 9.19 & $0.35-238.37$ & 0.182 \\
\hline Ouest Foire & 13.88 & $0.51-378.05$ & 0.119 \\
\hline Almadies & 35.56 & $1.47-862.54$ & 0.028 \\
\hline Université & 46.69 & $1.50-1449.39$ & 0.028 \\
\hline \multicolumn{4}{|l|}{ Habitat type } \\
\hline Man-made water collections & 1 & & \\
\hline Waterproof containers & 1.51 & $0.09-24.72$ & 0.771 \\
\hline Canals & 1.53 & $0.06-41.92$ & 0.801 \\
\hline "Céanes", cemented weels or basins & 3.65 & $0.23-58.63$ & 0.360 \\
\hline Swamp areas, marshes, ponds or lakes & 10.14 & $1.14-90.28$ & 0.038 \\
\hline Ditches or puddles & 33.47 & $4.05-276.48$ & 0.001 \\
\hline \multirow{3}{*}{$\begin{array}{l}\text { Presence of Culicinae larvae } \\
\text { No } \\
\text { Yes }\end{array}$} & & & $<0.001$ \\
\hline & I & & \\
\hline & 8.24 & $3.26-20.86$ & \\
\hline \multicolumn{4}{|c|}{ Larval density $(\mathbf{n}=\mathbf{8 6})$, GEE binomial regression model } \\
\hline \multirow[t]{2}{*}{ Habitat characteristics } & Risk Ratio & $95 \% \mathrm{Cl}$ & $\mathrm{P}$-value \\
\hline & & & $<0.001$ \\
\hline \multicolumn{4}{|l|}{$\begin{array}{l}\text { Study areas } \\
\text { Hann Maristes }\end{array}$} \\
\hline Université & 1.15 & $0.29-4.54$ & 0.838 \\
\hline Pikine & 2.00 & $0.86-4.66$ & 0.107 \\
\hline Ouest Foire & 5.03 & $2.09-12.53$ & 0.001 \\
\hline Almadies & 5.48 & $2.37-12.68$ & $<0.001$ \\
\hline Yarakh & 10.98 & $1.46-82.75$ & 0.020 \\
\hline \multicolumn{4}{|l|}{ Habitat type } \\
\hline Canals & 3.78 & $0.61-23.53$ & 0.155 \\
\hline "Céanes", cemented weels or basins & 9.53 & $1.08-83.91$ & 0.042 \\
\hline Ditches or puddles & 10.82 & $2.83-41.41$ & 0.001 \\
\hline Swamp areas, marshes, ponds or lakes & 23.29 & $5.16-105.04$ & $<0.001$ \\
\hline Man-made water collections & 48.16 & $4.55-509.71$ & 0.001 \\
\hline \multirow{3}{*}{$\begin{array}{l}\text { Water temperature } \\
<30^{\circ} \mathrm{C} \\
>=30^{\circ} \mathrm{C}\end{array}$} & & & $<0.001$ \\
\hline & ref. & & \\
\hline & 3.13 & $1.67-5.84$ & \\
\hline \multirow{3}{*}{$\begin{array}{l}\text { Surface vegetation }(\%) \\
<20 \% \\
>=20 \%\end{array}$} & & & 0.007 \\
\hline & ref. & & \\
\hline & 0.36 & $0.17-0.75$ & \\
\hline \multirow{3}{*}{$\begin{array}{l}\text { Presence of Culicinae larvae } \\
\text { No } \\
\text { Yes }\end{array}$} & & & 0.019 \\
\hline & ref. & & \\
\hline & 2.29 & $1.14-4.60$ & \\
\hline
\end{tabular}

Multivariate analysis with GEE logistic regression model or negative binomial regression model.

water collections in larval presence. In multivariate analysis, habitat type and presence of Culicinae larvae remained significant.

Higher larval densities were associated with water temperature $>=30^{\circ} \mathrm{C}$, surface vegetation covering less than $20 \%$ of the total surface area, co-occurrence of Culicinae larvae and habitat type. All four parameters remained significant in multivariate analysis.

These results are consistent with the known preference of An. gambiae s.l. for breeding in temporary pools $[27,41]$.
Co-occurrence of Anopheles and Culicinae larvae was previously reported in the literature [11]. Low-floating vegetation was also previously found as a determinant of the presence of anopheline larvae $[11,42]$.

The other physico-chemical parameters measured in the water collection sites were not significantly associated either with the occurrence or the abundance of larvae. Concerning turbidity, conflicting results were found in previous studies. Higher turbidity has been associated positively [42] or negatively [7] with the presence of anopheline larvae. In Dakar, Robert et al. found a prefer- 

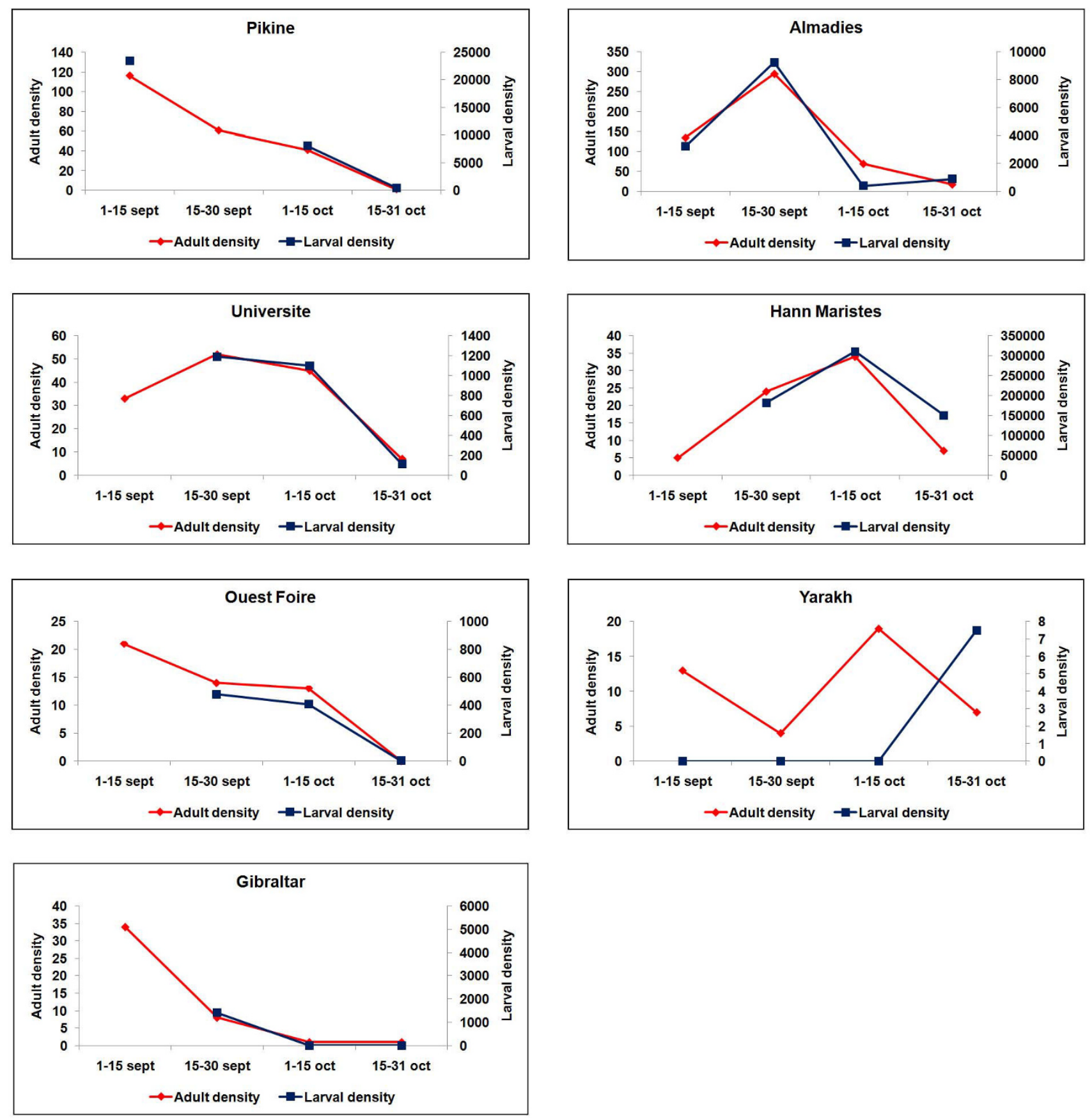

Figure 4

Graphical representation of An. gambiae s.l. aggressiveness (left scale, total number of Anopheles caught indoors and outdoors) and larval densities observed one week before adult catch and ponderated by the breeding habitats surface (right scale, larval density $\times$ surface water for all the breeding sites), for seven out of ten study areas of Dakar in September-October 2007. 
ence for breeding in clear water in the "céanes" [28]. As turbidity can be an indicator of particulate matter in suspension that could be food for larvae or polluting agents, its effect remains unclear. Even though water collection sites exposed to sunlight are known to provide breeding places for An. gambiae s.l. [27,41], the present study could not show any association with this parameter, probably because of a lack of contrast (i.e., very few water collection sites with no sunlight exposure) and the consequent lack of analysis power.

The presence of predator fish was not associated either with a lower probability of larvae or lower larval density. Finally, the period of prospection was associated neither with the presence of larvae nor with larval density.

One possible limitation of the data interpretation may have been the use of the dipping method, which could have failed to provide repetitive measures of larval densities even though the sampling location and the person collecting the samples were consistent throughout the study. The presence/absence of larvae was probably recorded correctly with this technique, especially for small habitats.

\section{Adaptation to urban settings}

The data recorded from water collection sites did not aim to measure pollution but anopheline larvae were sampled in bodies of water that, based on visual examination, appeared polluted. In urbanized environments such as the ones in the present study areas, it cannot be excluded that Anopheles can adapt to new conditions, as was previously shown in some studies. In Accra, An. gambiae s.l. evolution over a few decades led to a rise in breeding in domestic water and polluted water [6]. In Dar Es Salaam, An. gambiae s.l. bred in organically polluted habitats [7]. Anopheles gambiae s.s. larvae have been found in water polluted with heavy metals and oil in Lagos [8].

\section{Urban agriculture}

The importance of urban agricultural activity on malaria has been reported in several African cities, such as in Côte d'Ivoire and Ghana [10], where irrigation led to the emergence of larval habitats $[10,11]$ and higher malaria prevalence [12,13]. It has been suggested that irrigated vegetable fields around a French military camp in Abidjan could have been the source of the unexpectedly high number of adult Anopheles caught there [43]. In other cities such as Malindi in Kenya, no relationship has been found between household-level urban agriculture and the occurrence of bodies of water [44].

Two of the areas in the present study (Pikine and Yarakh) sustained urban agricultural activities, but no irrigation systems were in place. Watering was done manually every morning, with water coming from the "céanes." In both areas, infected adult Anopheles were caught on human bait. This was consistent with results in 2005-2006 where infected Anopheles have been caught in Dakar (district of Ouakam), close to market gardens [26].

Among the studied "céanes," only three (37\%) harboured larvae and the larval densities were very low. These results were consistent with those reported by Robert et al in 1998 , in which only 33\% of 48 "céanes" harboured anopheline larvae, with low densities [28]. Even though the presence of mosquito-eating fishes was not significantly associated with the presence/absence of larvae and larval density in the statistical analysis, these low larval densities could be partly linked to the systematic presence of larvivorous fishes, only allowing larvae to grow if they are hidden in the floating vegetation. These fishes were introduced in Dakar in the 1930s for larval control and their presence in the wells is recommended by the National Hygiene Service. In 1998, Awono-Ambéné et al [29] confirmed their utility, indicating that predation in the "céanes" was probably mainly due to fishes (Gambusia and Tilapia). Other factors which were not measured in this study, such as the use of pesticides, could also lead to low larval density in the "céanes". Furthermore, it is possible that in the rainy season temporary breeding sites were more attractive for breeding than the "céanes," as higher larval densities in the céanes were recorded at the end of the dry season but not during the rainy season [29].

In Pikine, some temporary and permanent breeding sites which were not linked to market-gardening were present, so it was difficult to measure the link between the agricultural activity and the adult Anopheles density. In contrast, water collections were highly related to urban agriculture in Yarakh but larval densities were low as previously described in Dakar [28], so it is probable that market-gardens provided resting sites to Anopheles rather than increased number of breeding sites, as was previously demonstrated in Ghana [45].

\section{Spatial scale of malaria transmission}

In the present study, a very close parallel was found between larval density index and adult densities. In six out of ten areas, it was possible to superimpose temporal variations in larval and adult densities. This correlation is consistent with the hypothesis of a malaria transmission system that is contained within the limits of the study areas. The larval habitats available in each area could be sources of adult mosquitoes, or at least were representative of the habitats available in a larger area providing the adult specimens caught on human bait. The parallel between larval density index and adult densities was not found by taking into account all areas together, as no information on population and building densities were available to balance the associations. 
The present results were consistent with the low dispersion (<300 metres) of Anopheles from their breeding habitats. In rural areas, dispersion can reach several kilometres, and it is highly reduced in urban settings, due to the high density of houses and the proximity of readily available hosts for blood meals. Several studies have highlighted the low dispersion of Anopheles in urban settings, its consequences in terms of heterogeneity of malaria transmission levels and its implications for the incidence of clinical malaria. In Pikine, a gradient of Anopheles density and malaria prevalence was shown on a 910-metre transect, going from the marshland to the city centre. Most of the An. arabiensis were caught at $<285 \mathrm{~m}$ from the marshland [14].

Similar examples also exist in other African cities. In Ouagadougou, Burkina-Faso, most of the An. gambiae s.l. females were collected within $300 \mathrm{~m}$ of the breeding sites located along a water reservoir [46] and the P. falciparum infections where concentrated in the human population living within $200 \mathrm{~m}$ of the hydrographic network [47]. In two cities in Cameroon, Anopheles densities recorded on hilly slopes (around $40 \mathrm{~m}$ high) were zero at 200 and 250 $\mathrm{m}$ from the swampy valleys where the breeding sites are concentrated [48]. In Edea, also in Cameroon, the EIR varied from 0 to 86 infective bites per person per year between houses within $200 \mathrm{~m}$ of each other, depending on their proximity to the breeding sites [49]. In Brazzaville, Congo, great heterogeneity of transmission was recorded between districts, ranging from more than 100 infective bites per person per year to less than one infective bite per person every three years [50]. Maps of malaria transmission intensity in Brazzaville showed that districts with very different malaria risk levels could be adjacent to each other [51]. In Uganda, proximity to the breeding habitats has been recognized as a risk factor for clinical malaria episodes at scales of a few hundred metres [15].

The method used in the present study for the measurement of larval densities accounted for all larval stages including pupae. The actual productivity of the breeding sites would have been better estimated by accounting for stage IV and pupae only, as the dynamics of larval mortality could differ depending on the type of breeding habitat [52]. To obtain such estimates, the larval sampling effort should be much greater. However, this is not a limitation in the present study, as the larval and adult densities were compared temporally within each study area. Since the figures were relative and not absolute, the comparisons were valid.

\section{Temporal dynamics of malaria transmission}

A very close parallel was found between the adult density and the larval density index but not between the adult density and the raw larval density if the latest was not adjusted on breeding sites surfaces. As water collection surfaces are driven by rainfall amounts and frequency of rainfall events, relationship between meteorological data and Anopheles larval and adult densities should be further investigated.

\section{Implications for malaria control}

Since the beginning of the 21st century, there has been renewed interest in larval control as part of an integrated malaria control strategy (including ITNs, indoors residual insecticide spraying and health care access) [53]. In urban settings, the human population density relative to the number of breeding sites is very high, so larval control could be effective [54].

Focusing on larval control in African urban areas could lead to satisfactory results, as was the case in Palestine/ Israel, Italy and the United States, where the modification or elimination of aquatic habitats was applied extensively and contributed significantly to the eradication of malaria transmission, especially in urban settings [55]. Regarding the An. gambiae complex, several reports of successful control efforts have been reported. In Ethiopia, environmental management led to a $49 \%$ reduction in An. arabiensis adult density [56]. In the city of Dar Es Salaam, the killing of larvae succeeded in significantly reducing malaria transmission and morbidity [57]. In Djibouti City, malaria has been controlled by larval control using larvivorous fishes [58]. In Brazil, An. arabiensis invaded the North-East region in the thirties and led to a ten-year malaria epidemic [59]. Focus on larval control made it possible to eradicate the vector and the disease [60] from the area while the proportion of temporary breeding sites was high, just as it is in Dakar.

In areas where transmission is low or moderate, focusing malaria control activities in limited areas should greatly improve their efficacy and their cost-effectiveness [16]. Thus, a good knowledge of mosquito dynamics and of the ecological requirements leading to the presence of breeding sites is crucial. A deep understanding could even help to target larval control to the most productive habitats, thus enhancing the efficacy of control [61]. The present study has shown that transmission in Dakar is highly focal, at scales of a few hundred metres, and that there is a high degree of correlation between larval and adult densities within each area. Furthermore, transmission is temporally focal and lasts only a few weeks. Even if productive habitats in Dakar show a great variety, they could be spatially and temporally identified; in this context, malaria control in Dakar could benefit from larval management.

\section{Conclusion}

In Dakar, malaria transmission exists and is highly focal. In order to spatially focus malaria control in the areas that are at greater risk, precise mapping of malaria transmission levels should be conducted. With new technologies 
such as Geographic Information Systems and Remote Sensing, associated with entomological and epidemiological work, the possibility of mapping the malaria risk in Dakar exists and should be further explored.

\section{Competing interests}

The authors declare that they have no competing interests.

\section{Authors' contributions}

VM was responsible for the study design, supervision of data collection, analysis, interpretation, production of the final manuscript and revisions. LG contributed to the supervision of data collection, data analysis, interpretation and production of the final manuscript. CV contributed to the study design, analysis and interpretation. FJ contributed to the data analysis. SB contributed to the data analysis. JPL contributed to overall scientific management, analysis, interpretation, preparation of the final manuscript and revisions. JFT contributed to overall scientific management, analysis, interpretation, preparation of the final manuscript and revisions. CR was responsible for overall scientific management, analysis, interpretation, preparation of the final manuscript and revisions. FP was responsible for overall scientific management, analysis, interpretation, preparation of the final manuscript and revisions. All authors read and approved the final manuscript.

\section{Acknowledgements}

This study received financial support from the Direction Générale de l'Armement (DGA - Contrat d'Objectif $\left.n^{\circ} 07 \mathrm{CO} 402\right)$ and the Centre National d'Etudes Spatiales (CNES).

We thank Dr. Antonio Güell and Murielle Lafaye, director and head of teleepidemiology applications, respectively, at the Application and Valorisation Office at CNES, for supporting this study. We acknowledge the CNES ISIS programme, which provided access to high spatial resolution SPOT5 images. We warmly thank Pape Ndiaye for commitment to the fieldwork in Dakar. We also thank all the families who kindly opened their homes to our team.

\section{References}

I. Wang SJ, Lengeler C, Smith TA, Vounatsou P, Cisse G, Diallo DA, Akogbeto M, Mtasiwa D, Teklehaimanot A, Tanner M: Rapid urban malaria appraisal (RUMA) in sub-Saharan Africa. Malar J 2005, 4:40.

2. Donnelly MJ, McCall PJ, Lengeler C, Bates I, D'Alessandro U, Barnish G, Konradsen F, Klinkenberg E, Townson H, Trape JF, Hastings IM, Mutero C: Malaria and urbanization in sub-Saharan Africa. Malar J 2005, 4:I2

3. Robert V, Macintyre K, Keating J, Trape JF, Duchemin JB, MW, Beier JC: Malaria transmission in urban sub-saharan Africa. $\mathrm{Am} \mathrm{J}$ Trop Med Hyg 2003, 68: 169-176.

4. Bogreau H, Renaud F, Bouchiba H, Durand P, Assi SB, Henry MC, Garnotel E, Pradines B, Fusai T, Wade B, Adehossi E, Parola P, Kamil $M A$, Puijalon $O$, Rogier $C$ : Genetic diversity and structure of African Plasmodium falciparum populations in urban and rural areas. Am J Trop Med Hyg 2006, 74:953-959.

5. Antonio-Nkondjio C, Simard F, Awono-Ambene P, Ngassam P, Toto JC, Tchuinkam T, Fontenille D: Malaria vectors and urbanization in the equatorial forest region of south Cameroon. Trans $R$ Soc Trop Med Hyg 2005, 99:347-354.
6. Chinery WA: Effects of ecological changes on the malaria vectors Anopheles funestus and the Anopheles gambiae complex of mosquitoes in Accra, Ghana. J Trop Med Hyg 1984, 87:75-8I.

7. Sattler MA, Mtasiwa D, Kiama M, Premji Z, Tanner M, Killeen GF, Lengeler $C$ : Habitat characterization and spatial distribution of Anopheles sp. mosquito larvae in Dar es Salaam (Tanzania) during an extended dry period. Malar J 2005, 4:4.

8. Awolola TS, Oduola AO, Obansa JB, Chukwurar NJ, Unyimadu JP: Anopheles gambiae s.s. breeding in polluted water bodies in urban Lagos, southwestern Nigeria. J Vector Borne Dis 2007, 44:24I-244.

9. Omlin FX, Carlson JC, Ogbunugafor CB, Hassanali A: Anopheles gambiae exploits the treehole ecosystem in western Kenya: a new urban malaria risk? Am J Trop Med Hyg 2007, 77:264-269.

10. Afrane YA, Klinkenberg E, Drechsel P, Owusu-Daaku K, Garms R, Kruppa T: Does irrigated urban agriculture influence the transmission of malaria in the city of Kumasi, Ghana? Acta Trop 2004, 89: 125-134.

II. Matthys B, N'Goran EK, Kone M, Koudou BG, Vounatsou P, Cisse G, Tschannen $A B$, Tanner $M$, Utzinger J: Urban agricultural land use and characterization of mosquito larval habitats in a medium-sized town of Cote d'Ivoire. J Vector Ecol 2006, 31:319-333.

12. Klinkenberg E, McCall PJ, Hastings IM, Wilson MD, Amerasinghe FP, Donnelly MJ: Malaria and irrigated crops, Accra, Ghana. Emerg Infect Dis 2005, I I: I 290- I 293.

13. Wang SJ, Lengeler C, Smith TA, Vounatsou P, Diadie DA, Pritroipa X, Convelbo N, Kientga M, Tanner M: Rapid urban malaria appraisal (RUMA) I: epidemiology of urban malaria in Ouagadougou. Malar J 2005, 4:43.

14. Trape JF, Lefebvre-Zante E, Legros F, Ndiaye G, Bouganali H, Druilhe $P$, Salem G: Vector density gradients and the epidemiology of urban malaria in Dakar, Senegal. Am J Trop Med Hyg 1992, 47:181-189.

15. Staedke SG, Nottingham EW, Cox J, Kamya MR, Rosenthal PJ, Dorsey G: Short report: proximity to mosquito breeding sites as a risk factor for clinical malaria episodes in an urban cohort of Ugandan children. Am J Trop Med Hyg 2003, 69:244-246.

16. Carter R, Mendis KN, Roberts D: Spatial targeting of interventions against malaria. Bull World Health Organ 2000, 78:|40|-|4||.

17. Diallo S, Konate L, Ndir O, Dieng T, Dieng Y, Bah IB, Faye O, Gaye $O$ : [Malaria in the central health district of Dakar (Senegal). Entomological, parasitological and clinical data]. Sante 2000, 10:221-229.

18. Diallo S, Ndir O, Faye O, Diop BM, Dieng Y, Bah IB, Dieng T, Gaye $O$, Konate $L$ : [Malaria in the southern sanitary district of Dakar (Senegal). I. Parasitemia and malarial attacks]. Bull Soc Pathol Exot 1998, 91 :208-213.

19. Rey M, Camerlynck P, Mar ID, Lafaix C, Sow A: [Paludism in the Dakar metropolitan area (from hospital experience)]. Bull Soc Med Afr Noire Lang Fr 1968, I 3:353-365.

20. Soumare M, Seydi M, Diop SA, Ba TA, Ndour CT, Dieng Y, Diop BM, Sow PS: [The place of malaria in an infectious disease department in Dakar, Senegal]. Med Trop (Mars) 2008, 68:485-490.

21. Imbert P, Sartelet I, Rogier C, Ka S, Baujat G, Candito D: Severe malaria among children in a low seasonal transmission area, Dakar, Senegal: influence of age on clinical presentation. Trans R Soc Trop Med Hyg 1997, 91 :22-24.

22. Sartelet H, Rogier C, Milko-Sartelet I, Angel G, Michel G: Malaria associated pre-eclampsia in Senegal. Lancet 1996, 347:I I 2 I.

23. Sarr D, Marrama L, Gaye A, Dangou JM, Niang M, Mercereau-Puijalon $O$, Lehesran JY, Jambou R: High prevalence of placental malaria and low birth weight in Sahelian periurban area. Am J Trop Med Hyg 2006, 75: I7|-I77.

24. Vercruysse J, Jancloes M: Etude entomologique sur la transmission du paludisme humain dans la zone de Pikine (Sénégal). Cah Orstom, Ser Ent Med Parasitol 1981, 19:165-178.

25. Diallo S, Konate L, Faye O, Ndir O, Faye M, Gueye A, Diouf M [Malaria in the southern sanitary district of Dakar (Senegal). 2. Entomologic data]. Bull Soc Pathol Exot 1998, 91 :259-263.

26. Pages F, Texier G, Pradines B, Gadiaga L, Machault V, Jarjaval F, Penhoat K, Berger F, Trape JF, Rogier C, Sokhna C: Malaria transmission in Dakar: a two-year survey. Malar J 2008, 7: 78. 
27. Gillies MT, Coetzee M: A supplement to the anophelinae of Africa south of the Sahara (Afrotropical region) The South African Institut for Medical Research No. 55 Johannesburg, South Africa; 1987.

28. Robert V, Awono-Ambene P, Thioulouse J: Ecology of larval mosquitoes, with special reference to Anopheles arabiensis (Diptera: Culcidae) in market-garden wells in urban Dakar, Senegal. J Med Entomol 1998, 35:948-955.

29. Awono-Ambéné HP, Robert V: Survival and emergence of immature Anopheles arabiensis mosquitoes in market-gardener wells in Dakar, Senegal. Parasite 1999, 6:179-184.

30. Burkot TR, Zavala F, Gwadz RW, Collins FH, Nussenzweig RS, Roberts DR: Identification of malaria-infected mosquitoes by a two-site enzyme-linked immunosorbent assay. Am J Trop Med Hyg 1984, 33:227-231

31. Mouchet J, Carnevale P, Coosemans M, Fontenille D, Ravaonjanahary C, Richard A, Robert V: Typologie du paludisme en Afrique. Sante 1993, 3:220-238.

32. Edwards FW: Mosquitoes of the Ethiopian Region. III. Culicine Adults and Pupae London: British Museum (Natural History); 194I.

33. Fanello C, Santolamazza F, della Torre A: Simultaneous identification of species and molecular forms of the Anopheles gambiae complex by PCR-RFLP. Med Vet Entomol 2002, 1 6:46I-464.

34. Service MW: Mosquito ecology New York: John Wiley and Sons Publishing; 1976.

35. Vercruysse J, Jancloes M, Velden L Van de: Epidemiology of seasonal falciparum malaria in an urban area of Senegal. Bull World Health Organ 1983, 61:821-831.

36. Bryan J: Anopheles gambiae and A. melas at Brefet, The Gambia, and their role in malaria transmission. Ann Trop Med Parasitol 1983, 77:1-12.

37. Mouchet J, Carnevale P, Coosemans M, Julvez J, Manguin S, RichardLenoble D, Sircoulon J: Biodiversité du paludisme dans le monde John Libbey Eurotext; 2004.

38. Dia I, Konate L, Samb B, Sarr JB, Diop A, Rogerie F, Faye M, Riveau $G$, Remoue F, Diallo $M$, Fontenille D: Bionomics of malaria vectors and relationship with malaria transmission and epidemiology in three physiographic zones in the Senegal River Basin. Acta Trop 2008, 105:145-153.

39. Diagne N, Fontenille D, Konate L, Faye O, Lamizana MT, Legros F, Molez JF, Trape JF: [Anopheles of Senegal. An annotated and illustrated list]. Bull Soc Pathol Exot 1994, 87:267-277.

40. Dia I, Diallo D, Duchemin JB, Ba Y, Konate L, Costantini C, Diallo M: Comparisons of human-landing catches and odor-baited entry traps for sampling malaria vectors in Senegal. J Med Entomol 2005, 42:104-109.

41. Gillies MT, De Meillon B: The Anophelinae of Africa south of Sahara (Ethiopian zoogeographical region) The South African Institut for Medical Research No. 54 Johannesburg, South Africa; 1968.

42. Gimnig JE, Ombok M, Kamau L, Hawley WA: Characteristics of larval anopheline (Diptera: Culicidae) habitats in Western Kenya. J Med Entomol 200I, 38:282-288.

43. Girod R, Orlandi-Pradines E, Rogier C, Pages F: Malaria transmission and insecticide resistance of Anopheles gambiae (Diptera: Culicidae) in the French military camp of Port-Bouet, Abidjan (Cote d'Ivoire): implications for vector control. J Med Entomol 2006, 43:1082-1087.

44. Keating J, Macintyre K, Mbogo CM, Githure JI, Beier JC: Characterization of potential larval habitats for Anopheles mosquitoes in relation to urban land-use in Malindi, Kenya. Int J Health Geogr 2004, 3:9.

45. Klinkenberg E, McCall P, Wilson MD, Amerasinghe FP, Donnelly MJ: Impact of urban agriculture on malaria vectors in Accra, Ghana. Malar J 2008, 7:151.

46. Sabatinelli G, Rossi P, Belli A: [Dispersion of Anopheles gambiae s.I. in an urban zone of Ouagadougou (Burkina Faso)]. Parassitologia 1986, 28:33-39.

47. Baragatti M, Fournet F, Henry MC, Assi S, Ouedraogo H, Rogier C, Salem G: Social and environmental malaria risk factors in urban areas of Ouagadougou, Burkina Faso. Malar J 2009, 8: I 3.

48. Manga L, Fondjo E, Carnevale P, Robert V: Importance of low dispersion of Anopheles gambia (Diptera: Culicidae) on malaria transmission in hilly towns in South Cameroon. J Med Entomol 1993, 30:936-938.

49. Robert V, Le Goff G, Toto JC, Mulder L, Fondjo E, Manga L, Carnevale P: Anthropophilic mosquitoes and malaria transmission at Edea, Cameroon. Trop Med Parasitol 1993, 44: I4-18.
50. Trape JF, Zoulani A: Malaria and urbanization in central Africa: the example of Brazzaville. Part II: Results of entomological surveys and epidemiological analysis. Trans $R$ Soc Trop Med Hyg | 987, 8 | (Supp| 2): | 0- | 8.

51. Trape J-F, Zoulani A: Malaria and urbanization in Central Africa: the example of Brazaville. Part III: Relationships between urbanization and the intensity of malaria transmission. Trans R Soc Trop Med Hyg 1987, 81:19-25.

52. Service MW: Mortalities of the immature stages of species $B$ of the Anopheles gambiae complex in Kenya: comparison between rice fields and temporary pools, identification of predators, and effects of insecticidal spraying. J Med Entomol 1977, 13:535-545.

53. Walker K, Lynch M: Contributions of Anopheles larval control to malaria suppression in tropical Africa: review of achievements and potential. Med Vet Entomol 2007, 2 I:2-2I.

54. Keiser J, Utzinger J, Caldas de Castro M, Smith TA, Tanner M, Singer $\mathrm{BH}$ : Urbanization in sub-saharan Africa and implication for malaria control. Am J Trop Med Hyg 2004, 7 I: I I8-I27.

55. Kitron U, Spielman A: Suppression of transmission of malaria through source reduction: antianopheline measures applied in Israel, the United States, and Italy. Rev Infect Dis I989, I I:391-406.

56. Yohannes M, Haile $M$, Ghebreyesus TA, Witten $K H$, Getachew A, Byass $P$, Lindsay SW: Can source reduction of mosquito larval habitat reduce malaria transmission in Tigray, Ethiopia? Trop Med Int Health 2005, I 0: I 274- 1285.

57. Fillinger U, Kannady K, William G, Vanek MJ, Dongus S, Nyika D, Geissbuhler Y, Chaki PP, Govella NJ, Mathenge EM, Singer BH, Mshinda H, Lindsay SW, Tanner M, Mtasiwa D, de Castro MC, Killeen GF: A tool box for operational mosquito larval control: preliminary results and early lessons from the Urban Malaria Control Programme in Dar es Salaam, Tanzania. Malar J 2008, 7:20.

58. Louis JP, Albert JP: [Malaria in the Republic of Djibouti. Strategy for control using a biological antilarval campaign: indigenous larvivorous fishes (Aphanius dispar) and bacterial toxins]. Med Trop (Mars) 1988, 48:127-I3I.

59. Parmakelis A, Russello MA, Caccone A, Marcondes CB, Costa Forattini OP, Sallum MA, Wilkerson RC, Powell JR: Historical analysis of a near disaster: Anopheles gambiae in Brazil. Am J Trop Med Hyg 2008, 78: I76-I78.

60. Killeen GF, Fillinger U, Kiche I, Gouagna LC, Knols BG: Eradication of Anopheles gambiae from Brazil: lessons for malaria control in Africa? Lancet Infect Dis 2002, 2:618-627.

61. Wu W, Utzinger J, Novak RJ: Habitat-based larval interventions: a new perspective for malaria control. Am J Trop Med Hyg 2008, 78:2-6.

Publish with Bio Med Central and every
scientist can read your work free of charge
"BioMed Central will be the most significant development for
disseminating the results of biomedical research in our lifetime."
Sir Paul Nurse, Cancer Research UK
Your research papers will be:
- available free of charge to the entire biomedical community
- peer reviewed and published immediately upon acceptance
- cited in PubMed and archived on PubMed Central
• yours - you keep the copyright
Submit your manuscript here:
http://www.biomedcentral.com/info/publishing_adv.asp

